\title{
TAKSİ, DOLMUŞ VE BENZERİ ULAŞIM ARAÇLARINDA ÇALIŞANLARIN SIGGORTALILIKLARI
}

\author{
Gizem SARIBAY ÖZTÜRK*
}

\section{$\ddot{O} Z$}

Ticari taksi, dolmuş ve benzeri şehir içi toplu taşıma araçları günlük hayatımızda önemli bir yer tutmaktadır. Bu araçların ve araçlarda çalışan kişilerin sayıları günden güne artış göstermektedir. Adı geçen araçların bir klsmında araç sahipleri kendileri, bir kısmında araçları sahibinden kiralamak suretiyle kendi adlarına işletenler ve bir kısmında ise iş sözleşmesiyle işçiler çalışmaktadır. Şehir içi toplu taşıma araçlarında çalışma, çoğu zaman gece-gündüz devam etmekte, çalışanların günlük mesaileri gündüz, akşam veya gece şeklinde değişmektedir. Hatta bir kişi gün içinde farklı saatlerde birden fazla araçta çalışabilmektedir. Çalışanların çoğu ne yazık ki kayıt dışı çalışmaktadır. 5510 sayılı Sosyal Sigortalar ve Genel Sağlık Sigortası Kanunu Ek. m. 6 ile 01.03.2011 tarihinden itibaren uygulanmak üzere, ticari taksi, dolmuş ve benzeri şehir içi toplu taşıma araçlarında çalı̧̧anların kısmî süreli iş sözleşmesiyle bir ayda 10 günden az çalışanlarına, primlerinin kendileri tarafindan ödenmesi kaydiyla, özel bir sigortalılık sağlanmıştır. Çalışmamızda taksi, dolmuş ve benzeri şehir içi toplu taşıma araçlarında çalışan kişilerin sosyal sigortalılıkları ve dolayısıyla da sosyal güvenliklerine ilişkin hükümler değerlendirilmeye çalışılacaktır.

Anahtar Kelimeler: Taksi şoförleri, toplu taşıma araçlarında çalışanlar, kayıt dışı çalışma, 5510 sayılı Sosyal Sigortalar ve Genel Sağlık Sigortası Kanunu, Ek. m. 6.

\section{THE SOCIAL SECURITY OF THE PEOPLE WORKING IN TAXIS, MINIBUSES AND SIMILAR PUBLIC TRANSPORTATION}

\section{ABSTRACT}

Commercial taxis, minibusses and similar public transportation vehicles play a significant role in our daily lives. The quantity of these vehicles and individuals working in these vehicles increases every day. Some owners of these transportation vehicles utilize their own vehicles and some operate these vehicles on their own

\footnotetext{
Dr., İTÜ İşletme Fakültesi, İşletme Mühendisliği Bölümü, İş ve Sosyal Güvenlik Hukuku (saribay@itu.edu.tr)
}

ORCID ID: 0000-0001-8038-6713

DOI : :10.34246/ahbvuhfd.682789

Yayın Kuruluna Ulaştığı Tarih $\quad$ : 23/07/2019

Yayınlanmasının Uygun Görüldü̈̆̈̈ Tarih: 10/01/2020

Ankara Hacı Bayram Veli Üniversitesi Hukuk Fakültesi Dergisi C. XXIV, Y. 2020, Sa. 1219 
behalf by leasing from the proprietor. In a portion of the vehicles mentioned above, individuals work with a labour contract. In urban public transport, work is frequently carried out day and night, and the employees' shifts change from day to day. Some days the shifts are in the evening and the next the night. In fact, one person can work in more than one vehicle at various occasions during the day. Social Security and Universal Health Insurance Act No. 5510, via Annex Article 6 and as of 01.03.2011, a special insurance is available to employees who work with a part time contract in commercial transportaion vehicles for a period of less than 10 days in a month, provided that their premiums are paid by themselves. In this study, the provisions regarding the social insurance and thus social security of the people working in commercial transportation vehicles will be evaluated.

Keywords: The people working in taxis, the people working in public transportation vehicles, undeclared work, Social Security and Universal Health Insurance Act No. 5510, Annex Article 6.

\section{GİRIŞ}

Meslek odalarının kayıtlarına göre ülkemizde yaklaşık 3 bin taksi durağı, 60 bin ticari taksi ve 100 bine yakın da ticari taksi şoförü bulunmaktadır ${ }^{1}$. Kayıt dışılık nedeniyle resmi kayıtlarda görünmeyen sayının bu rakamların çok üzerinde olduğu bilinmektedir. Diğer taraftan dolmuş ve benzeri ulaşım araçlarında çalışan kişi sayısı da azımsanmayacak kadar çoktur. Sözü edilen kişilerin sosyal güvenliklerine ilişkin sorunlar yıllardır çözülmeyi beklemektedir.

Şehir içi toplu taşıma araçlarında çalışma çoğu zaman gece gündüz devam etmekte, çalışanların günlük mesaileri gündüz, akşam veya gece şeklinde değişmektedir. Hatta bir kişi gün içinde değişik saatlerde birden fazla araçta çalışabilmektedir. Klasik çalışma şekillerinden oldukça farklı olan bu iş, çalışma süreleri açısından olduğu kadar, kişilerin sürekli trafikte olmaları sebebiyle iş kazası riskinin yoğunluğuyla da dikkat çekmektedir.

5510 say1lı Sosyal Sigortalar ve Genel Sağlık Sigortası Kanunu’na 6111 sayılı Kanunun 51' inci maddesiyle 'Bazı kısmi süreli çalışanların sigortalılıkları" başlıklı Ek. m. 6 eklenmiştir². Ek. m. 6 ile şehir içi toplu taşıma araçlarında çalışanların sigortalılığına ilişkin olarak yeni hükümler getirilmiştir. Anılan düzenleme, 01.03.2011 tarihinden itibaren uygulamaya

1 MÜLAYIM.

26111 sayıl1 Kanun (RG, S. 27857 (Mükerrer), T. 25.02.2011). 
konulmuştur. Kanun koyucu, kendi deyimiyle, kayıtdışılığın önüne geçmek için, Ek. m. 6 kapsamına giren kişileri çalışmalarına göre kısmi ve tam süreli olarak ikiye ayırmış, ay içerisinde belirli bir sürenin altında çalışanlar için farklı hükümler getirmiştir.

Ek. m. 6'da, ticari taksi, dolmuş ve benzeri şehir içi toplu taşıma araçlarında çalışan kişilerden bir veya birden fazla kişi yanında kısmi süreli iş sözleşmesiyle bir ay içinde çalışma saati süresine göre hesaplanan çalışma gün sayıs1 10 günden az olanların, kendileri tarafından 30 gün üzerinden prim ödemeleri suretiyle, sigortalı olabilecekleri düzenlenmiş̦ir³ .

Ek. m. 6 hükmüne ilişkin madde gerekçesine göre, "Kayıtlı çalışmanın artırlması amacıyla ticari taksi dolmuş ve benzeri nitelikteki şehir içi toplu taşıma aracı işyerlerinde klsmi süreli iş sözleşmeleriyle ay içerisinde bir veya birden fazla kişi tarafindan çalıştırılan ve bir kişiye tabi olarak çalışma saati süresine göre belirlenen gün saylsı 10 günden az olan kişilerin sosyal güvenliklerinin madde kapsamında sağlanması öngörülmektedir"”.

Öğretide Ek. m. 6 ile sosyal güvencesiz çalışan taksi, dolmuş, özel halk otobüsü şoför ve muavinlerinin güvencesiz yaşamlarının bir nebze güvenceli hale getirilmeye çalışıldığ 1 haklı olarak ifade edilmektedir ${ }^{5}$. Ancak kanaatimizce kayıtlı çalışmayı artırmak için asıl yapılması gereken, denetimlerin artırılması suretiyle kayıt dışı çalışanları sistemin içine almaktır ${ }^{6}$. Kayıtlı çalışmanın artırılması için denetimler sırasında trafik polisinin ehliyet, ruhsat ve trafik sigortası sorarken, araçta çalışanın sigortasını da rutin olarak kontrol etmesi çok daha uygun bir çözüm olurdu. Söz konusu denetimlerin sıklaştırılması beklenen hedefe ulaşmayı hızlandırırdı ${ }^{7}$.

Çalışmamızda taksi, dolmuş ve benzeri şehir içi toplu taşıma araçlarında iş sözleşmesiyle çalışan kişilerin sosyal sigortalılıkları ve dolayısıyla da sosyal güvenliklerine ilişkin hükümler değerlendirilmeye çalış1lacak ve yeri geldikçe olması gereken hukuk bakımından eleştirilerde ve önerilerde bulunulacaktır.

3 GÜZEL /OKUR /CANIKLİOĞLU, s. 135; MÜLAYIM; SEGEKAM.

46111 sayılı Kanuna ilişkin Tasarının 50. Maddesinin gerekçesi için bkz. https://www.tbmm. gov.tr/sirasayi/donem23/yil01/ss606.pdf, erişim: 2.3.2019.

5 TUNCAY /EKMEKÇİ, s. 328.

6 CANIKLIOĞLU /ÖZKARACA, s. 645.

7 ŞAKAR, (2011), s. 9-10.

Ankara Hacı Bayram Veli Üniversitesi Hukuk Fakültesi Dergisi C. XXIV, Y. 2020, Sa. 1221 


\section{ARAÇ SAHİPLERİ İLE ARACI KENDİ ADINA VE HESABINA IŞLETENLER}

Taksi, dolmuş ve benzeri araçların bir kısmında araç sahipleri araçlarını kendileri kullanmaktadır. Belirtilen kişiler, iş sözleşmesi ile bir işverene bağlı olarak değil, kendi adına ve hesabına çalışmaktadır. Elbette uygulamada, gün içerisinde kendisi çalıştığı gibi işçi çalıştıran ve bu nedenle işveren statüsünü haiz kişiler de bulunmaktadır.

5510 sayılı Sosyal Sigortalar ve Genel Sağlık Sigortası hükümlerine göre, hizmet akdine bağlı olmaksızın kendi adına ve hesabına bağımsız çalışanlardan gelir vergisinden muaf olup, esnaf ve sanatkâr siciline kayıtlı olanlar, m. 4/1, (b) kapsamında sigortalı say1lmaktadırlar (5510 sK. m. 4/I,b). 2011/36 sayıl1 SGK Genelgesinde ${ }^{8}$ de adı geçen kişilerin m. 4/1, (b) bendi kapsamında sigortalı sayıldıkları belirtilmiştir. Hükme göre, gelir vergisinden muaf olup esnaf ve sanatkar siciline kayıtlı olanlar, Kanunun m. 4/1, (b) bendinin (2) numaralı alt bendi kapsamında sigortalı sayıldıklarından; taksi, dolmuş ve minibüslerde şoförlük mesleğini geçim kaynağ 1 olarak seçmiş olduğunu ve sürekli olarak icra ettiğini beyan edip ilgili meslek odasına, kooperatiflere, meslek odasının bulunmadığı yerlerde ise şoförler odasına üye olanlar, esnaf ve sanatkar sicil müdürlüğ̈̈ne kayıt yaptırmak mecburiyetinde olup, m. 4/1, (b) bendi kapsamında sigortalıdır (2011/36 say1l Genelge m. 2.4.1).

Araç sahipleri gerçek veya basit usulde gelir vergisi mükellefi olmaları nedeniyle m. 4/1, (b) bendi kapsamında sigortalı sayılmışlardır. Bu kişilerin sigortalılığı, gerçek veya basit usulde gelir vergisi mükellefi oldukları tarih itibariyle başlar (5510 m. 7/1, (b)). Başlangıç tarihi, vergi dairelerince sigortalı işe giriş bildirgesi düzenlenerek on beş gün içinde Sosyal Güvenlik Kurumu'na bildirilir. Sistem içerisinde sigortalılığın sağlanması için araç sahiplerinin kendilerini bildirmeleri aranmadığından, sözü edilen kişilerin sosyal güvenlik kapsamı dışında kalmaları söz konusu değildir. Adı geçen araç sahiplerinin sosyal güvenlikleri tam olarak sağlanmıştır9.

Şehir içinde ticari taksi, dolmuş ve benzeri nitelikteki diğer toplu taşıma araçlarının sahibi olanlar gibi bu araçları sahibinden kiralamak suretiyle kendi adlarına işletenler de yer almaktadır. 2918 sayılı Karayolları Trafik Kanunu

\footnotetext{
8 SGK Başkanlığı Sosyal Sigortalar Genel Müdürlüğünün 05.04.2011 tarihli, 2011/36 say1l1, "6111 sayı1ı Kanun Uyarınca Yapılacak Sigortalama ve Borçlanmaya İlişkin İşlemler" konulu Genelgesi.

9 YILMAZ /ÇAKAR, s. 5.
} 
gereğince hazırlanan Karayolları Trafik Yönetmeliği'ne göre, araç sahibi dışında başka bir kişinin aracı kendi hesabına ve tehlikesi kendisine ait olmak üzere işletmesi ve araç üzerinde fiili tasarrufu bulunması halinde, bu işlerden dolayı vergi mükellefiyetlerinin tesis edilmesi nedeniyle, aracı kendi adına ve hesabına işletenler, 5510 sayılı Kanun m. 4/1, (b) kapsamında sigortalı sayılmaktadırlar (2011/36 sayılı Genelge m. 2.4.1, 2). Dolayısıyla şehir içinde ticari taksi, dolmuş ve benzer nitelikteki diğer toplu taşıma araçlarını sahibinden kiralamak suretiyle kendi adlarına işletenler de araç sahipleri gibi, 5510 sayılı Kanun'da bağımsız çalışanlar; eski sistemde ise Bağ-Kur'lu olarak isimlendirilmek suretiyle zorunlu olarak sosyal güvenlik kapsamına alınmışlardır.

Uygulamada ticari taksi sahiplerinin taksi plakalarını alt1 ay veya bir yıllığına kiraya verdikleri, ticari taksinin işletilmesini tamamen aracı kiralayan kişiye bıraktıkları görülmektedir. Bu durumda taraflar arasındaki ilişkinin hasılat kirası olduğu kabul edilmektedir (TBK. m. 357-378). Ticari taksi sahiplerinin bir kısmı ise esas olarak takside kendisi çalışmakta; ancak günün belli bir diliminde (çoğu zaman gece) aracı başka bir şoföre tahsis etmektedir. Çalışma karşılığında elde edilen gelir ne olursa olsun sabit bir miktar taksi sahibine ödenmekte veya taraflar arasındaki güven ilişkisinin niteliğine bağlı olarak elde edilen gelirin belli bir oranı taksi sahibine verilmektedir. Bu durumda taraflar arasındaki ilişkinin hasılat kirası mı yoksa iş sözleşmesi mi olduğu meselesi ise somut olayın koşullarına göre titizlikle değerlendirilmesi gereken bir sorundur. Yapılan değerlendirmenin sonucuna bağlı olarak, kişinin iş sözleşmesi ile çalıştığı sonucuna varılırsa, Ek. m. 6'l1 olması mümkün olacak; taraflar arasındaki ilişkinin hukuki niteliğinin hasılat kirası olduğu kanaatine varıldığı takdirde ise kişi m. 4/I, (b) kapsamında sigortalı sayılacaktır ${ }^{10}$.

\section{ARAÇLARDA ÜCRETLİ VE IŞS SÖZLEŞMESIYLE ÇALIŞANLAR}

\section{Ek. m. 6'nın Kapsamı}

\section{a. Ek. m. 6 Kapsamında Olanlar}

Taksi, dolmuş ve buna benzer şehir içi toplu taşıma araçlarında iş sözleşmesiyle ücretli çalışanlar; tam ve kısmi süreli çalışma yapanlar olmak

10 Ticari taksi şoförü ile taksiyi sürekli yahut günün belirli saatlerinde kiralayan kişi arasındaki ilişkinin hukuki niteliği hakkında bir Yargıtay Hukuk Genel Kurulu kararı için bkz. YHGK, E. 2015/9-3561, K. 2018/77, https://www.kararara.com/forum/viewtopic. php? $\mathrm{f}=45 \& \mathrm{t}=444434$, erișim: 24.05 .2019 . 
üzere ikiye ayrılmaktadır. Adı geçen kişilerden ücretli olarak ay içinde bir veya birden fazla kişi yanında kısmi süreli iş sözleşmesiyle, 10 günden az süreyle çalışanların sigortalılıkları Ek. m. 6 ile özel olarak düzenlenmiştir.

Ek. m. 6 hükmü ile çalışmanın tespitinde, çalışanların çalıştıkları kişi yanında ay içerisinde çalışma saati süresine göre hesaplanan çalışma gün sayısının 10 günden az veya en az 10 gün olması temel ayırt edici unsur olarak belirlenmiştir. Dolayısıyla, ay içindeki çalışma süresinin nasıl hesaplanacağı önem arz etmektedir. Ancak Kanunda sözü edilen konuda açık bir hüküm yoktur. 5510 sayılı Kanunun "Prime esas kazanç" başlıklı m. 80/I, (h) hükmü yol gösterici olacaktır. Düzenlemeye göre, "Sigortalıların günlük kazançlarının hesabında esas tutulan gün sayıları, aynı zamanda, bunların prim ödeme gün sayılarını göstermektedir. Ancak, işveren ve sigortalı arasında kısmî süreli hizmet akdinin yazılı olarak yapılmış olması kaydıyla, ay içerisinde günün bazı saatlerinde çalışan ve çalıştığ 1 saat karşı1ığında ücret alan sigortalının ay içindeki prim ödeme gün sayısı, ay içindeki toplam çalışma saati süresinin 4857 sayılı İş Kanununa göre belirlenen haftalık çalışma süresine göre hesaplanan günlük çalışma saatine bölünmesi suretiyle bulunmaktadır. Bu şekildeki hesaplamada gün kesirleri bir gün kabul edilmektedir" (m. 80/I, (h)). 4857 sayılı İş Kanununa göre haftalık çalışma süresi genel olarak 45 saattir (m. 63). Kanunda günlük çalışma süresinden söz edilmemişse de, hafta tatili bir gün olduğundan cumartesi gününün iş günü olduğu da göz önünde tutulduğunda, haftalık toplam çalışma süresi altı güne bölünmeli ve günlük çalışma süresi $(7,5)$ saat olarak belirlenmelidir. Dolayısıyla Ek. m. 6 kapsamındaki kişinin haftada veya ay içinde kaç gün çalıştığının tespiti için kişinin ay içindeki toplam çalışma süresinin günlük çalışma süresi olan $(7,5)$ 'a bölünmesi gerekmektedir ${ }^{11}{ }^{12}$. Yapılacak hesaplamalarda 7,5 saatin altındaki çalışmalar 1 güne tamamlanmaktadır (Sosyal Sigorta İşlemleri Yönetmeliği m. 101/3).

11 CANIKLIOĞLU/ÖZKARACA, s. 646.

12 Nitekim SSIY.'nin, “Kısmi süreli çalışmalarda prim ödeme gün sayısı” başlıklı 101. maddesi, "İşsözleşmesi saat ücreti karşıllı̆̆ yapılmış ise kısmi süreli çalışan sigortalıların ay içinde çalıştığı toplam sürenin, 4857 sayılı İs Kanununa göre günlük olağan çalışma süresi olan 7 , 5 saate bölünmesiyle, sigortalı için bildirilmesi gereken prim ödeme gün sayısı hesaplanır. Bu şekilde yapılacak hesaplamalarda 7, 5 saatin altındaki çalışmalar 1 güne tamamlanır." şeklindedir (f.III).

Ancak aynı maddenin 2. fikrasında yer alan, "Kısmi süreli çalışma, işveren ile sigortalının yazılı olarak yapılan iş sözleşmesinin niteliğine bağll, aylık ücret karşıllğ̆ çalışma biçiminde imzalanmışsa, sigortalı haftalık çalışma süresine bakılmaksızın tam ay olarak bildirilir." şeklindeki hüküm Sosyal Sigorta İşlemlerinde Değişiklik Yapılmasına Dair Yönetmelik ile yürürlükten kaldırılmıştır. (Bkz. RG.,17.04.2012, 28267). 
Örneğin Ek. m. 6 kapsamındaki kişi, ortalaması 7,5 saatten 9 güne denk gelecek şekilde çalıştıktan sonra, 1 saat daha çalışsa, toplamda 68,5 saat çalışmasına rağmen son güne denk gelen 1 saatlik çalışma 1 güne tamamlanmakta ve önceki 9 günlük çalışmayla birlikte ayda 10 günlük çalışma söz konusu olmaktadır. Buna göre, kişinin Ek. m. 6 kapsamında sigortalı olması için ay içinde toplam 67,5 saatten fazla çalışmamış olması gerekmektedir.

Ek. m. 6 hükmü ile çalışmanın tespitinde, çalışanların çalıştıkları kişi yanında ay içerisinde çalışma saati süresine göre hesaplanan çalışma gün sayıs1, hükmün uygulanacağı kişileri belirleyici olduğundan, "10 günden az" çalışmanın ne anlama geldiği üzerinde de durulmalıdır. Hükmün lafzını dikkate aldığımızda, 9 gün ve altında çalışanların Ek. m. 6 kapsamına gireceği anlaşılmaktadır. Ancak öğretide kanun koyucunun birçok Kanunda anılan rakamı da dahil ettiğ $1^{13}$ göz önüne alınarak tam 10 gün çalışanların da Ek. m. 6'ya tabi olabilecekleri ifade edilmiştir ${ }^{14}$. Kanaatimizce " 10 günden az" tabiri, 9 gün ve altında çalışmadır. Zira, hükmün lafzı tereddüte imkan vermediği gibi, Genelge ve Kanundaki ifade de birebir örtüşmektedir.

Ek. m. 6, kanun kapsamına alınacak çalışanların, şehir içi toplu taşıma araçlarında çalışmasını öngörmektedir. Dolayısıyla şehir içi toplu taşıma işyerleri kavramının da aydınlatılması gerekmektedir. Karayolu Taşıma Yönetmeliği'nde ${ }^{15}$ bir şehrin belediye sınırları içinde kalan alan, şehir içi olarak tanımlanmıştır (m. 4/yy). Herhangi bir ilin herhangi bir noktasından veya yerleşim biriminden başlayıp diğer bir ilin herhangi bir noktasında veya yerleşim biriminde biten taşımalar ise şehirlerarası taşıma sayılmakta olup Ek 6' ncı maddeye tabi müracaatlarda bu husus dikkate alınarak işlem yapilmaktadir ${ }^{16}$.

Sosyal Güvenlik Kurumu, 2013/11 sayıl1 Genelge ile 5510 sayıl1 Kanunun Ek. m. 6 hükmünün kapsamına girecek kişileri detaylandırmıştır. Genelgeye göre, 5510 sayılı Kanunun Ek 6' nc1 maddesinde ticari taksi,

13 Örneğin, 5510 sayılı Kanun m. 6/I-b'deki "üçüncü dereceye kadar hısımlar" ibaresinin, üçüncü derece dahil olarak düzenlenmesi, 4857 sayılı İş Kanunu m. 68/I-b'deki “yedibuçuk saate kadar" ibaresinin yedibuçuk saat dahil olarak anlaşılacağı açıkça düzenlenmiştir (ŞAKAR, (2011), s.10'da dn. 4).

14 ŞAKAR, (2011), s. 3-4.

15 RG, S. 20295, T. 08.01.2018.

16 2013/11 say1lı Genelge, Üçüncü Bölüm, 2.1

Ankara Hacı Bayram Veli Üniversitesi Hukuk Fakültesi Dergisi C. XXIV, Y. 2020, Sa. 1225 
dolmuş ve benzeri nitelikteki şehir içi toplu taşıma araçlarında kısmi süreli çalışanlar sigortalı sayılmakta olduğundan, şehir içi toplu taşıma araçlarının (taksi, dolmuş, otobüs) geliş ve gidiş saatlerini kaydeden, bekleyen yolcuların sıra düzenini sağlayan ve araçlara binme işini organize eden kişiler (değnekçi, kahya, simsar, çı̆̆ırtkan vb. isimlerle adlandırılan) ücretlerini günlük ya da haftalık olarak dolmuş hattındaki şoförlerden almakta olduklarından, bunların Ek 6' nci maddeye tabi sigortal1l1k talepleri de kabul edilmektedir ${ }^{17}$.

Diğer taraftan, zorunlu eğitim kapsamındaki okul öncesi ve diğer öğrenci taşıma hizmetlerini düzenli ve güvenli hale getirmek amacıyla taşıma yapacak gerçek ve tüzel kişilerin yeterlilik ve çalışma şartları belirlenmiş olup, araçlarda okul öncesi çocukları ve/veya ilköğretim öğrencilerini taşıyan okul servis araçlarında, araç içi düzenini sağlayan, öğrencilerin araca iniş ve binişlerinde yardımc1 olan rehber personel bulundurulmas1 zorunludur ${ }^{18}$. 2013/11 sayıl1 Genelgeye göre, kısmi süreli olarak çalışan bu kişiler, müracaatları halinde Ek 6' ncı madde kapsamında sigortalı olabileceklerdir ${ }^{19}$. Şehiriçi toplu taşıma işlerinin ihale yoluyla alınması halinde, araçlarda çalışan sigortalılar hakkında ise Ek 6'nci madde hükümlerinin uygulanması mümkün değildir ${ }^{20}$. Kanaatimizce bu tür hususların Genelgeyle değil de Kanun ile düzenlenmesi daha yerinde olacaktır.

\section{b. Ek. m. 6 Kapsamı Dışında Kalanlar}

Taksi, dolmuş ve benzeri şehir içi toplu taşıma araçlarında ücretli ve tam süreli olarak, başka bir deyişle ay içerisinde çalışma saati süresine göre hesaplanan çalışma gün sayısı 10 gün ve üzerinde olanlar, Ek. m. 6 kapsamı dışında bırakılmışlardır. Anılan kişiler, iş sözleşmesi ile çalışanların sigortalılı̆̆ını düzenleyen genel hüküm olan m. 4/1, (a) kapsamında sigortalı sayılmaktadırlar. Taksi, dolmuş ve benzeri şehir içi toplu taşıma araçlarında ücretli ve tam süreli olarak çalışan kişileri çalıştıran araç sahipleri veya arac1 işletenler ise işveren sıfatı ile çalışanları sigortalı yapmak zorundadır. Sosyal güvenliğe ilişkin tüm yükümlülükler ilgili işverenler üzerinde devam etmekte; örneğin taksi veya dolmuşun sahibi ya da işleticisi sigortalı işe giriş bildirgesi

2013/11 say1lı Genelge, Üçüncü Bölüm, 28/2/2014 tarihli ve 2014/5 say1lı Genelge ile Ek olarak getirilmiştir.

18 28/8/2007 tarihli ve 26627 sayılı Resmi Gazetede yayımlanan Okul Servis Araçları Hizmet Yönetmeliği m. 5/I, b.

19 2013/11 sayılı Genelge, Üçüncü Bölüm, m. 2/son.

20 2013/11 say1l Genelgeye Ek, 3/7/2015 tarihli ve 2015/19 sayılı Genelge. 
vermekte, işyeri tescilini, çıkış işlemlerini yapmakta ve sigorta primlerini ödemektedir.

Ek. m. 6 hükmünde, iş sözleşmesiyle ve ay içerisinde çalışma saati süresine göre hesaplanan çalışma gün sayısı 10 günden az olan çalışanlar esas olarak düzenlemekle birlikte, aynı maddede kimlerin Ek. m. 6'lı olamayacağ 1 tek tek sayılmıştır.

Ek. m. 6/VII hükmüne göre, 5510 sayılı Kanun kapsamında tam süreli çalışma ile uzun vadeli sigorta kollarına tabi olan sigortalılar ile 506 say11 Kanunun geçici 20’ nci maddesi kapsamındaki sigortalılar ve kendi sigortalılıklarından dolayı gelir veya aylık almakta olanlar, birinci fikrada belirtilen çalışma durumları nedeniyle ayrıca sigortalı olmazlar. 2013/11 say11 Genelgede ${ }^{21}$ de, Ek 6' ncı madde kapsamında sigortalı olabilmek için Kanunda yazılanlara ek olarak Kanunun 4' üncü maddesinin birinci fikrasının (b) ve (c) bentlerine tabi sigortalı olmamak ve isteğe bağlı sigortalı olmamak gerektiği belirtilmiştir ${ }^{22}$.

Konuya ilişkin mevzuata göre, taksi, dolmuş ve benzeri nitelikteki şehir içi toplu taşıma araçlarında çalışan kişinin, 5510 sayılı Kanunun Ek 6. maddesi kapsamında sigortalı olabilmesi için Ek 6. maddede belirtilen araçlarda bir veya birden fazla işveren tarafindan ay içerisinde 10 günden daha az süre ile çalıştırılması gerekmektedir. Diğer taraftan, kişi yapılan çalışmalar dışında iş sözleşmesine tabi, kendi adına ve hesabına bağımsız veya kamu görevlisi olarak veya 506 sayılı Kanunun Geçici 20’ye (banka sand1klarına) tabi çalışmamalı, 18 yaşını doldurmuş olmalı ${ }^{23}$, isteğe bağlı sigortalı olmamalı, ve Kurum'dan kendi sigortalılığından dolayı gelir veya aylık almamalıdır.

İlgili hükümleri tespit ettikten sonra, Ek. m. 6'lı olamayacağı belirlenen kişilerden bir kısmının, Ek. m. 6 kapsamına gireceğinin kabul edilmesi gerektiği kanaatinde olduğumuzu belirtelim. Bunlardan ilki, Ek. m. 6 kapsamına girecek bir işte çalışmakla birlikte, bir de kısmi süreli çalışması olanlardır. Örneğin uygulamada Ek. m. 6 sigortalısı toplamda 10 günün altında kalmak üzere başka bir işverenle kısmi süreli iş sözleşmesi imzalamadan bir iki günlük işler için anlaşmakta; fakat Ek. m. 6 sigortalısı olduğunu yeni işverene bildirmediği için kişinin m. 4/I, (a)’lı olarak işe girişi yapılmakta veya kişi m.

\footnotetext{
$21 \quad$ SGK'nın Sigortalılık İşlemleri Hakkında 2013/11 sayılı Genelgesi.

22 Benzer yönde bkz. ALPER, s. 106.

23 ŞAKAR, (2017), s. 101.
} 
4/I, (a)'lı olarak kısmi süreli bir işte çalışmaktayken, Ek. m. 6 kapsamında sigortalı olabileceği bir araçta çalışmaya başlamaktadır. İlk ihtimalde, kişinin m. 4/I, (a)'lı olarak başka bir işe girmesi halinde, Ek. m. 6 sigortalılığ sona ermektedir. İkinci ihtimalde ise m. 4/I, (a)'lı olarak çalışmaktayken, Ek. m. 6 kapsamında sayılması gereken çalışmasından ötürü, Ek. m. 6 kapsamında sigortalı olması mümkün olmamaktadır. İlgili mevzuata da yer vermek suretiyle, aşağıda konuya ilişkin görüşümüz açıklanmaya çalışıımıştır.

Ek. m. 6/VII, "Bu Kanun kapsamında tam süreli çalışma ile uzun vadeli sigorta kollarına tabi olan sigortalılar ile 506 sayılı Kanunun geçici 20 nci maddesi kapsamındaki sigortalılar ve kendi sigortalılıklarından dolayı gelir veya aylık almakta olanlar, birinci fıkrada belirtilen çalışma durumları nedeniyle ayrıca sigortalı olmazlar"” ş̧eklindedir.

Kanun koyucu tam süreli çalışanların, Ek. m. 6 kapsamında sigortalı olamayacağını düzenlemiş, ardından "ile" bağlacı ile uzun vadeli sigorta kollarına tabi sigortalıların da aynı şekilde Ek. m. 6'lı olamayacağını eklemiştir. Hüküm kelime kelime okunduğunda, tam süreli çalışmalar zikredilmesine rağmen kısmi süreli çalışmalar zikredilmediği için, kişinin kısmi süreli iş sözleşmesiyle çalışırken, Ek. m. 6 kapsamına girecek bir başka çalışmasının olması halinde, bu çalışmanın Ek. m. 6 kapsamında kalacağı anlaşılmaktadır. Buna karşın, Ek. m. 6/VII'de, tam süreli çalışanlardan sonra gelen "ile uzun vadeli sigorta kollarına tabi çalışanlar" ibaresi çelişki yaratmaktadır. Zira uzun vadeli sigorta kollarına tabi olmak, tam süreli veya kısmi süreli çalışma ile mümkündür. O halde Ek. m. 6/VII'nin başında neden tam süreli çalışmanın ayrıca zikredildiği anlaşılmamaktadır. Kanun koyucu sadece uzun vadeli sigorta kollarına tabi çalışması olanların Ek. m. 6'lı olamayacağını düzenleseydi, kanaatimizce yerinde olmamakla birlikte, hüküm çelişkili olmazdi.

Ek. m. 6/VII'nin ifade ettiğimiz çelişkili lafzı, 2011/36 sayılı Genelge 2.4.1.1'de verilen bir örnekte detaylandırılmıştır. Örneğe göre "Şehir içinde dolmuş şoförü olarak ayda 9 gün, ticari takside de ayda 15 gün şoför olarak çalışan sigortalı Ek 6' ncı madde kapsamında talepte bulunmuştur. Sigortalı 15 günlük çalışması nedeniyle 4' üncü maddenin birinci fikrasının (a) bendi kapsamında sigortalı sayıldığından dolmuş şoförlüğü nedeniyle 9 günlük çalışmasından dolayı Ek 6' ncı madde kapsamında sigortalı olamayacaktır. Ancak, sigortalıya ay içinde eksik kalan 15 günü 4' üncü maddenin birinci fikrasının (a) bendi kapsamında isteğe bağlı sigorta primi ödeyebileceği 
ya da aynı statü üzerinden 41 inci maddenin (i) bendi uyarınca borçlanma yapabileceği hakkında bilgi verilecektir"'24.

Öğretide, kişinin dolmuş şoförü olarak yaptığı çalışma nedeniyle Ek. m. 6'dan yararlanmasının mümkün olmadığı mevcut mevzuata göre açıksa da, yapılan çalışmanın m. 4/I, (a) kapsamında kabul edilmesi ve dolmuş şoförünü çalıştıran işverenin prim ödeme yükümlülüğünün olması gerektiği belirtilmiştir. Zira, artık Ek. m. 6'nın kapsamına giren bir çalışan söz konusu olmadığına göre, şoförün 9 günlük çalışmasına ilişkin sigorta primleri, işveren tarafından genel esaslara göre ve tüm sigorta kolları için Sosyal Güvenlik Kurumuna ödenmelidir. Lafzı çok müsait olmasa da, bu düzenlemenin Ek. 6. maddenin kapsamı dışında kalma ile sınırlı olarak anlaşılması gerektiği, aksine bir yorumun kayıtdıșı sigortalı çalıștırmaya bir kanun hükmü ile olanak sağlayacağı, bunun isabetli olmadığının açık olduğu ifade edilmiştir ${ }^{25}$. Adı geçen görüş, haklı olarak Ek. m. 6 ve Genelgenin ilgili düzenlemesinin, yorum yoluyla düzeltilmesi gerektiğinden hareketle, uygulamaya yönelik bir çözüm getirmiştir.

Ek. m. 6/VII'de yer alan çelişkili ifadenin, Genelgeyle sosyal güvenlik hukukunun temel prensiplerini bertaraf edecek şekilde örneklenmesinin kabul edilemeyeceği belirtilmelidir. Sosyal güvenlik hukukunda kural, sigorta ilişkisinin zorunlu olarak kurulmasıdır. Kişinin herhangi biri işte çalışması halinde, ücret alması, ücretten prim kesilmesi ve dolayısıla da sigortalı olma zorunluluğu bulunmaktadır. Aksi durumda Ek. m. 6 kapsamına girecek kişinin yine aynı hüküm uyarınca kayıt dışına itilmesi söz konusu olacaktır. Ek. m. 6 ile kendine özgü bir sigortalılık oluşturulduğu açıktır. Ancak kendine özgü olma, sosyal güvenlik hukukunun temellerini yerinden oynatmamalıdır. 2013/11 say1lı Genelgede de benzer örnekler verilmiş ve kişinin Ek. m. 6'l1 olamaması halinde, kişiye isteğe bağlı sigortalı olabileceğinin veya borçlanma yapabileceğinin bildirileceği ifade edilmiştir. Kişinin hangi gerekçeyle isteğe bağlı sigortalı olacağ 1 yahut bu süreyi neden borçlanacağı anlaşılamamaktadır. Uygulama açısından konuyu değerlendirdiğimizde de sonuç farklı olmayacaktır. Ay içinde kısmi süreli iş sözleşmesiyle 20 gün çalışmış kişinin geliri, zaten 20 günlüktür. Kural olarak işçinin emeğinden başka geliri

\footnotetext{
24 2013/11 sayılı Genelgede verilen başka bir örnek de benzer şekildedir. Örneğe göre, "20 gün kısmi süreli sözleşmeyle uzun vadeli sigorta kollarına çalışan kişi, ayrıca ticari takside ay içinde 10 günden az çalışmaktadır. Sigortalının takside yaptığı çalışma gereğince Ek. m. 6' lı olması mümkün değildir” (Üçüncü Bölüm, Ek. m. 6 Kapsamında Çalışanlar).

25 CANIKKLIOĞLU/ ÖZKARACA, s. 643, benzer yönde KÖME AKPULAT, s. 1207.
} 
olmadığ için, çalışılmayan, dolayısıyla ücret alınmayan ve boşta kalan 10 günlük sürenin priminin sigortalı tarafindan isteğe bağlı ödenmesini yahut sigortalının eksik süreyi borçlanmasını beklemek hiç de gerçekçi değildir. Sözü edilen kişiye, kalan sürelerde Ek. m. 6 kapsamına girecek şekilde iş bulması halinde, çalışması ve ücret alarak geçimini sağlamasının yanında primlerini de ödeyebilme imkanı tanınmalıdır. Tüm bu gerekçelerle, Ek. m. 6/VII'de yer alan "tam süreli çalışma ile uzun vadeli sigorta kollarına tabi olan sigortalılar ..." şseklinde devam eden hükümden "uzun vadeli sigortalı" ibaresinin çıkartılması gerektiği kanaatindeyiz. Değişikliğin yapılması halinde, kişi ay içinde kısmi süreli iş sözleşmesiyle çalışırken, bir de şehir içi toplu taşıma işinde çalışırsa, Ek. m. 6 kapsamında sigortalı olabilecek ve sosyal güvenliğin zorunluluğu ilkesi zedelenmeyecek, kayıt dışı çalışma azalacaktır.

Ek. m. 6/VII gereği, Ek. m. 6 kapsamında olamayacak bir diğer grup kendi sigortalılıklarından dolayı gelir veya aylık almakta olan kişilerdir. Böyle bir sonuç da, sosyal güvenlik hukukunun temel ilkeleri ile bağdaşmamaktadır. Öğretide, sürekli iş görmezlik geliri alan bir sigortalının Ek. m. 6'nın kapsamı dışında kalmakla birlikte, on günden az olan çalışması nedeniyle tüm sigorta kollarına tabi olacağı ve sosyal sigorta primleri, genel hükümler uyarınca ödeme yükümlüsü işveren olmak üzere, sigortalı ve işveren tarafindan karşılanacağı ifade edilmiştir ${ }^{26}$. Olması gereken hukuk açısından söz konusu görüşe tamamen katılmakla birlikte, kanaatimizce yürürlükteki hukuk açısından sürekli iş göremezlik geliri almaktayken, şehir içi toplu taşıma araçlarında yaptığ ${ }_{1}$ on günden az diğer çalışması sebebiyle m. 4/I, (a)'l1 olması ve/veya işvereninin herhangi bir prim ödeme yükümlülüğünün bulunması mümkün değildir. Yapılması gereken, Ek. m. 6/VII'de yer alan "kendi sigortalılıklarından dolayı gelir veya aylık almakta olanların" Ek. m. 6 sigortalısı olamayacağı yönündeki ifadenin hükümden çıkartılmasıdır. Böylece sadece sürekli iş göremezlik geliri alanların değil, yaşlılık aylığı alanların da Ek. m. 6 kapsamına girecek bir işte çalışması halinde, yaptıkları çalışma kayıtdışı kalmayacaktır.

Kendi sigortalılıklarından dolayı gelir veya aylık alanların Ek. m. 6 sigortalılı̆̆ından yararlanamayacağ 1 hükmü̈ ${ }^{27}$ çerçevesinde, örneğin ölüm geliri veya ölüm aylığı alanların Ek. m. 6 sigortalısı olup olmayacağına da değinmek gerekmektedir. Sosyal güvenlik sistemimizde ölüm aylığı veya

\footnotetext{
26 CANIKLİĞLUL/ÖZKARACA, s. 644.

27 Ek. m. 6/VIII ve 2011/36 sayılı Genelge gereği.
} 
ölüm geliri, sigortalının kendi sigortalılığı nedeniyle alabileceği bir gelir olmadığından, ölüm geliri veya ölüm aylığı alanların, Ek. m. 6 sigortalısı olmaları mümkündür.

Ek. m. 6'lı olamayacağı belirlenen kişilerden, Ek. m. 6 kapsamına gireceğinin kabul edilmesi gerektiği kanaatinde olduğumuz bir diğer grup, isteğe bağlı sigortalı olduğu dönemde, Ek. m. 6 kapsamında bir işte çalışmaya başlayanlardır.

Sosyal Güvenlik Kurumunun 2013/11 sayılı Genelgesinde, Ek. m. 6 kapsamında sigortalı olmak için isteğe bağlı sigortalı olmamak gerektiği düzenlenmiştir. Kanunda yer almayan böyle bir koşulun Genelge ile getirilmesi sorgulanmalıdır. Zira bu yaklaşım, zorunlu sigortalılığın asıl, isteğe bağlı sigortalılığın ikincil olması ilkesine ters düşmektedir. Hüküm, isteğe bağlı sigortaya zorunlu sigortalılık karşısında üstünlük sağlamaktadır. $\mathrm{Bu}$ sebeplerle Kanuna aykırı olduğu gibi sosyal güvenlik hukukunun genel ilkelerine de aykırıdır ${ }^{28}$. Kişinin çalışması varsa, çalışması karşılığında kişi ücret alacak, sigortalı olacak ve sigortalı için prim ödenecektir. Ek. m. 6 kapsamındaki çalışmanın sona ermesi halinde ise isteğe bağlı sigortalı olarak devam etmek elbette mümkündür.

2013/11 sayılı Genelgedeki isteğe bağl1 sigortalılık ibaresi, sigortal1 olarak çalışmakla birlikte, ay içerisinde 30 günden az çalışan ya da tam gün çalışmayan sigortalılar için söz konusu olabilen bir isteğe bağlı sigortalılık olarak anlaşılırsa, Ek. m. 6 sigortalısının isterse Ek. m. 6'dan isterse de isteğe bağlı sigorta hükümlerinden yararlanabileceği kabul edilebilir. Ancak Ek. m. 6'da bunun aksinin kabulünü gerektirecek ifadeler yer almaktadır. Örneğin, maddenin ilk fikrası bir tercih hakkı bulunduğuna ilişkin hiçbir emare içermeyecek şekilde kaleme alındığı gibi, aynı yerde açıkça kimlerin Ek. m. 6'lı olabilecekleri zikredilmiştir. 8. fikrada da Kuruma, Ek. m. 6 sigortalısı olacak kişileri çalıştıranlara ve çalıştıranların bağlı olduğu meslek odası, birlik veya benzeri kuruluşlara belirli süreler içinde sigortalıların işe başlama ve işten ayrılışlarını bildirmeleri hususunda zorunluluk getirme yetkisi tanınmıştır. Yine 9. fikrada ise bildirim ve kontrol yükümlülüklerinin yerine getirilmemesi halinde idari para cezası uygulanacağı öngörülmüştür ${ }^{29}$. Dolayısıyla burada Ek. m. 6 sigortalısının isterse Ek. m. 6'dan isterse de isteğe bağlı sigorta hükümlerinden yararlanabileceği yönünde bir tercihin getirildiğini kabul etmek, ne yazık ki mümkün gözükmemektedir.

\footnotetext{
28 CANIKLİĞLU/ÖZKARACA, s. 644, 661.

29 CANIKLIOĞLUU/ÖZKARACA, s. 662.
} 
Olmas1 gereken hukuk bakımından ise 2013/11 sayılı Genelgenin "Kanunun Ek. m. 6. Maddesi Kapsamında Çalışanlar" başlıklı Üçüncü Bölümünde yer alan Ek. m. 6 kapsamında sigortalı olmak için isteğe bağlı sigortalı olmama koşulunun kaldırılması gerektiği kanaatindeyiz. Genelgede yer verilen ibare kaldırılana kadar ise Genelge ile Kanuna aykırı bir hüküm getirilemeyeceğinden hareketle; isteğe bağlı sigortalılığı bulunan kişinin, Ek. m. 6 kapsamında çalışmaya başlaması halinde, isteğe bağlı sigortalılığın kalkarak kişinin Ek. m. 6 kapsamında sigortalı olduğunun kabul edilmesi, çalışılmayan günleri ise isteğe bağlı sigortadan tamamlayabileceğinin kendisine bildirilmesi yerinde olacaktır.

Diğer taraftan, her ne kadar geniş yorum yapmak suretiyle aksi savunulabilecek olsa da, $5510 \mathrm{sK}$. m. 41/i'de düzenlenen borçlanma imkanı 4857 sayılı Kanuna göre kısmi süreli iş sözleşmesi ile çalışan sigortalıların, kısmi süreli çalıştıkları aylara ait eksik süreler için getirildiğinden, kişinin iş sözleşmesi ile çalışması halinde uygulanabilir. Oysa taksi, dolmuş gibi toplu taşıma araçlarında çalışanların tamamı 4857 sayılı Kanun kapsamında çalışmamaktadır. Zira 4857 sayılı İşK. m. 4/I, (1)'ya göre 507 sayılı Esnaf ve Sanatkarlar Kanununun 2. maddesinin tarifine uygun üç kişinin çalıştığ 1 işyerlerinde çalışanlar, İş Kanunu kapsamı dışındadır. İş Kanunu kapsamı dışında kalan kişilere, haklarında özel bir Kanun düzenlenmemişse, Türk Borçlar Kanununun (TBK'nın) iş sözleşmesine ilişkin hükümleri uygulanacaktır. Nitekim şehir içi taksi ve dolmuşları gibi toplu taşıma işyerlerinde çalışanlara ilişkin özel bir Kanun bulunmadığı için, anılan kişilere, TBK'nın ilgili hükümleri uygulanacaktır. Dolayısıyla dikkat edilmesi gereken bir diğer sorun, TBK. kapsamında kalan ve şehir içi toplu taşıma araçlarında çalışanların, ay içinde eksik kalan süreleri borçlanmasının mümkün olmayabileceğidir. Bu noktada $5510 \mathrm{sK}$. m. 41/i dar yorumlanırsa, Ek. m. 6'lı olamadığı için kendisine borçlanma imkanı verilebilecek kişinin, TBK'lı olması sebebiyle sıkıntı yaşayabileceği bir not olarak düşülmelidir.

Mevcut mevzuat değerlendirildiğinde, Ek. m. 6 kapsamı dışında tutulan bir diğer grubun ise taksi, dolmuş gibi şehir içi toplu taşıma araçlarında, birden çok çalıştıran yanında, her biri 10 günden az olmak üzere çalışma yapanlar olduğu anlaşılmaktadır. Zira Ek. m. 6/I gereği, ticari taksi, dolmuş ve benzeri nitelikteki şehir içi toplu taşıma aracı işyerlerinde kısmi süreli iş sözleşmesiyle bir veya birden fazla kişi tarafından çalıştırılan ve çalıştıkları kişi yanında ay içerisinde çalışma saati süresine göre hesaplanan çalışma gün sayısı 10 günden az olan kişilerin sigortalılıkları, bu madde kapsamında kendileri tarafından 30 gün üzerinden prim ödemeleri suretiyle sağlanır. Hükmün lafzından, 30 gün üzerinden prim ödenme koşulunun, "sigortalı olma koşulu" 
olarak düzenlendiği anlaşılmaktadır. Prim ödemenin sigortalılık koşulu olarak düzenlenmesi, sigortalılığın zorunluluğu ilkesine aykırı olsa da, Ek. m. 6 kendine özgü bir sigortalılık hali olarak değerlendirilebilir. Kaldı ki, prim ödemenin sigortalılık koşulu olarak düzenlenmesi 5510 sK. ile isteğe bağlı sigortalılık için de kabul edilmiştir. İsteğe bağlı sigortalılığ 1 düzenleyen $\mathrm{m}$. $51 \mathrm{ve} \mathrm{m} .52$ 'de benzer şekilde, geriye doğru 12 ay içinde ödenmeyen süreler sigortalılık süresinden sayılmamaktadır.

Konuyla ilgili hükümleri değerlendirdiğimizde, dikkat çeken bir diğer madde Geçici m. 29 olacaktır. Geçici m. 29 ile Ek. m. 6 kapsamında sigortalı olanlara, geçici bir süre için, daha az gün karşılığı prim ödemelerine rağmen otuz gün üzerinden prim ödemiş gibi sayılma imkanı getirilmiştir. Kanaatimizce, adı geçen hükümden de, Ek. m. 6'lı olabilmek için prim ödemenin zorunlu olmadığ 1 şeklinde bir sonuca varmak mümkün değildir. Geçici m. 29 ile 30 gün üzerinden prim ödemek suretiyle sigortalı olacağ1 kabul edilen kişiye, sadece bir süre için prim ödeme konusunda kolaylık sağlanmıştır. Bu noktada, yerinde bulmamakla birlikte, Ek. m. 6 kapsamında sigortalı olacak kişinin birden çok araçta, her birinde 10 günden az süreyle çalışması halinde, sadece ilk bildirilen çalışma, Ek. m. 6 kapsamında sigortalı kabul edilebilir. Nitekim, sosyal güvenlik merkezlerindeki uygulamanın da aynı şekilde olduğu görülmektedir. Oysa, Ek. m. 6 gibi, kendine özgü bir sigortal11ık hali olarak düzenlenen Ek. m. 9 kapsamında ev hizmetlerinde çalışan kişilerin aynı ayda birden çok işveren yanında çalışması halinde, her bir çalışma Ek. m. 9 kapsamında sayılmaktadır. Aşağıda öncelikle Ek. m. 9 hükmüne yer verilecek, ardından her iki hüküm üzerinden karşılaştırmalı bir değerlendirme yapılacaktır.

5510 say1l Kanun Ek. m. 9 "Ev hizmetlerinde bir veya birden fazla gerçek kişi tarafından çalıştırılan ve çalıştıkları kişi yanında ay içinde çalışma saati süresine göre hesaplanan çalışma gün sayısı 10 gün ve daha fazla olan sigortalılar hakkında Kanunun 4 üncü maddesinin birinci fikrasının (a) bendi kapsamındaki sigortalılara ilişkin hükümler uygulanır" ş̧eklindedir. Ek. m. 9 ile ev hizmetlerinde çalışanların aylık çalışma saati süresine göre $\mathbf{1 0}$ gün ve fazla çalışmaları, aynı Ek. m. 6 kapsamında çalışanlar gibi, m. 4/I, (a) kapsamında kabul edilmiştir. Ay içinde 10 günün altındaki çalışmalar için ise özel hükümler getirilmiştir.

Ev hizmetlerinde bir veya birden fazla gerçek kişi tarafından çalıştırılan ve çalıştıkları kişi yanında ay içinde çalışma saati süresine göre hesaplanan çalışma gün sayısı 10 günden az olanlar için çalıştırıldıkları süreyle orantılı olarak çalıştıranlarca 82. maddeye göre belirlenen prime esas günlük kazanç 
alt sınırının \%2'si oranında iş kazası ve meslek hastalığ1 sigortası primi ödenir." “““...Bu fikra kapsamına girenler, adlarına ödenen priminin ait olduğu ayı takip eden ayın sonuna kadar aynı kazancın otuz katının \%32,5 oranında prim ödeyebilir. Bunun \%20'si malullük, yaşlılık ve ölüm sigortaları, $\% 12,5$ 'i genel sağlık sigortası primidir. Bu süre içinde ödenmeyen primin ödenme hakkı düşer." (Ek. m. 9/II). Ev Hizmetlerinde 5510 Sayılı Kanunun Ek 9'uncu Maddesi Kapsamında Sigortalı Çalıştırılması Hakkında Tebliğ ${ }^{30} \mathrm{~m}$. 5/I'de de sigortalıların aynı ay içinde birden fazla gerçek kişi yanında, ay içinde 10 günden az ve/veya 10 gün ve daha fazla süre ile çalışabileceği düzenlenmiştir. Tüm bu hükümlerin değerlendirilmesi neticesinde, ev hizmetinde çalışan kişinin, bir çalıştıran yanında ayda 10 günden az çalıştıktan sonra, aynı ay içinde bir başka çalıştıran yanında daha 10 günden az çalışırsa, her çalışması için Ek. m. 9 sigortalısı olabildiği anlaşılmaktadır. Sigortalılarının uzun vadeli sigorta kollarından faydalanıp faydalanmayacakları meselesi, Ek. m. 9 kapsamındaki sigortalıların tercihlerine bırakılmıştır. Ek. m. 6'lılar ise ilk çalışmada zaten 30 günlük primi sigortalılık koşulu olarak ödedikleri için kazançları 30 gün olmasa da, 30 gün üzerinden (Geçici 29 saklı kalmak üzere) prim ödemektedirler. Kaldı ki, Ek. m. 6'ya ilişkin hiçbir kaynakta "Ev Hizmetlerinde 5510 Sayılı Kanunun Ek 9'uncu Maddesi Kapsamında Sigortalı Çalıştırılması Hakkında Tebliğ m. 5/I'de yer alan "sigortalıların aynı ay içinde birden fazla gerçek kişi yanında, ay içinde 10 günden az ve/veya 10 gün ve daha fazla süre ile çalışabileceği” benzeri bir hüküm düzenlenmemiştir. $\mathrm{Bu}$ sebeplerle Ek. m. 6 kapsamındaki sigortalılar, bir çalıştıran yanında ay içindeki 10 günden az çalışma süresine sahip sonraki çalışmalar için Ek. m. 6'lı kabul edilmemektedir ve kanaatimizce bu durum yerinde değildir. Ek. m. 6'lılardan farklı olarak, Ek. m. 9 kapsamındaki sigortalı, birden fazla kısmi süreli sözleşme ile 10 günden az süreyle çalıştırıldığında, çalıştığ tamamı için aldığı ücret üzerinden sigorta primini ödemektedir. Daha açık bir deyişle, sigortalı birden fazla çalıştıran yanında, ayda her biri 10 günden az olmak üzere hem çalışma imkanına sahip olmakta ve geçimini sağlamakta hem de çalışması karşılığında sigorta primlerini ödeme gücüne erişmektedir.

Taksi, dolmuş ve benzeri şehir içi toplu taşıma araçlarında çalışanların birden çok işveren yanında, ayda toplamda 10 günden fazla çalışmaları halinde, Ek. m. 6'lı olamayacağı, anılan kişilerin m. 4/I,(a)'lı olacağ 1 yönündeki Ek. m.6 hükmü, m. 4/I, (a)'lı olmanın aslında sigortalının daha lehine olmas1 gerekçesiyle yerinde görülebilir. Ancak ülke gerçekleri göz önüne alındığında

$30 \quad$ RG, S. 29313, T. 01.04.2015. 
gerçeğin farklı olduğu anlaşılacaktır. Taksi, dolmuş gibi şehiriçi toplu taşıma araçlarında iş sözleşmesiyle ay içerisinde çalışma saati süresine göre bir veya birden fazla işveren tarafından, toplamda ayda 10 günden fazla çalışıldığında, taksi sahiplerinin /taksiyi işletenlerin şoförü m. 4/I, (a) çerçevesinde sigortalı yapmaları gerekmektedir ki, bu ihtimalde, araç sahipleri/aracı işletenler işveren sayılacaklar ve işverene ait tüm yükümlülükler bu kişiler üzerinden beklenecektir. Şoförün birden çok işverenin taksisinde çalıştığı ve taksi sahibine diğer çalışmalarını haber vermediği ihtimalde, işverenlerin sosyal sigorta yükümlülüklerine ilişkin uygulamalar bakımından büyük sorunlar ortaya çıkacaktır. Çalışanın birden çok işverenin yanında ancak her birinde ayda 10 günden az çalışması halinde, işçi haber verse dahi, başkaca bir teşvik yahut denetim getirilmediği müddetçe, taksi sahipleri ne yazık ki, çoğunlukla çalışanları sigortalatmayacak, sistem nasıl geldiyse öyle devam edecektir. Hedef kayıt dışılığı önlemek ve sigortalıların sosyal güvenliklerini tam olarak sağlamak olduğundan, elbette öncelikli önerimiz Ek. m. 6'nın kaldırılarak, etkin bir denetim mekanizmasının geliştirilmesi, adı geçen kişilerin tamamının m. 4/I, (a)'lı olması ve taksi, dolmuş ve benzeri şehir içi taşıma araçlarında çalışanların kendine özgü durumları için de istisnai hükümler getirilmesidir. Ancak mevcut sistem üzerinden düzeltme yapılacaksa, "Ev Hizmetlerinde 5510 Sayılı Kanunun Ek 9'uncu Maddesi Kapsamında Sigortalı Çalıştırılması Hakkında Tebliğ m. 5/I'de yer alan "sigortalıların aynı ay içinde birden fazla gerçek kişi yanında, ay içinde 10 günden az ve/veya 10 gün ve daha fazla süre ile çalışabileceği” benzeri bir düzenleme, açık bir Kanun hükmü olarak, Ek. m. 6'ya eklenmelidir. Başka bir deyişle, her bir çalıştıran yanında ayda 10 günden az çalışmanın varlığı halinde, kişinin her bir çalışması için Ek. m. 6 kapsamında sigortalı olmasına imkan verilmeli, sigortalı olmak için çalış1mayan süre de dahil olmak üzere toplamda 30 günlük prim ödeme şartı kaldırılmalı ve 30 gün üzerinden prim ödeme tercihe bağlı kılınmalıdır. Böylece kişinin Ek. m. 6'lı olabileceği işlerde çalışıp, kalan sürenin primini 30 güne tamamlayıp tamamlamama kararı kendi takdirine bırakılmalıdır. Aksi halde, sigortal1 10 günden az süreyle Ek. m. 6 kapsamına girecek bir araçta çalışması halinde, Ek. m. 6 sigortalısı olduktan sonra, aynı ay içindeki 10 günden az diğer bir araçtaki çalışması için Ek. m. 6 sigortalısı olamamaktadır. Dolayısıyla kişi bir çalıştıran yanında çalışmasına rağmen, bu çalışması kapsam dışında kalacaktır. Kanun yoluyla kayıt dışı çalışmanın desteklenmesi şeklinde yorumlanabilecek bu düzenlemenin yerinde görülmesi, kanaatimizce mümkün değildir. 


\section{Sigortalılığın Başlangıcı}

5510 sayıl1 Kanunun Ek 6' nc1 maddesi kapsamında sigortalı olmak isteyenler öncelikle, işvereniyle "kısmi süreli iş sözleşmesi" imzalamalıdır. Ardından 2011/36 sayılı Genelgenin 13 nolu ekinde bulunan "Şehir İçi Toplu Taşıma Araçlarında Kısmi Süreli Çalışanlara Ait Giriş Bildirgesi” ve araç sahibiyle çalışan arasında imzalanan kısmi süreli iş sözleşmesi ile çalıştıkları ilin sosyal güvenlik il müdürlüğüne/sosyal güvenlik merkezine müracaat edeceklerdir. Çalışanın ay içerisinde birden fazla toplu taşıma aracı sahibinin yanında çalışması veya yeni bir toplu taşıma aracı sahibiyle çalışmaya başlaması halinde, her bir araç sahibiyle imzalanan kısmi süreli iş sözleşmeleri Kuruma verilecektir.

Ticari araç sahipleri tarafından 10 günden az çalıştırılan kişilerin Ek 6' ncı madde kapsamında sigortalı sayılması durumunda 10 günden az çalışılan süre için ticari araç sahibi tarafından başka bir bildirim yapılmayacaktır (2011/36 say1lı Genelge m. 2.4.1.1).

"Şehir İçi Toplu Taşıma Araçlarında Kısmi Süreli Çalışanlara Ait Giriş Bildirgesi" nde toplu taşıma aracı sahibinin (taksi, dolmuş ve diğer toplu taşıma araçları) ay içinde 10 günden az çalıştırdığı sigortalıya ilişkin beyanı ile Ek 6' ncı madde kapsamında sigortalı olacak kişinin beyanı bulunur. Söz konusu bildirge ayrıca toplu taşıma aracı sahibinin bağlı olduğu oda (şoförler odası, minibüsçüler odası, otobüsçüler odası ve diğer) ya da meslek Kooperatiflerince onaylanır. Toplu taşıma aracı sahibinin beyanı ve bağlı olduğu odanın onayının bulunmadığı bildirgelerin işleme alınması mümkün değildir (2011/36 sayılı Genelge m. 2.4.1.1).

5510 sayılı Kanunun Ek 6' ncı maddesi kapsamında sigortalı olmak için müracaat eden ticari araçlarda kısmi süreli olarak çalışanların sigortalılığ "Şehir İçi Toplu Taşıma Araçlarında Kısmi Süreli Çalışanlara Ait Giriş Bildirgesi" nin Kuruma verildiği tarih itibariyle başlatılır. Sigortalılı̆̆ın başlangıç tarihinin belirlenmesinde SSIYY'nin 124 üncü maddesi hükümleri doğrultusunda işlem yapılır (2011/36 sayılı Genelge m. 2.4.1.1). Bu demektir ki, adi posta veya Kuruma doğrudan yapılan başvuru ve bildirimlerde, başvuru veya bildirimin Kurumun gelen evrak kayıtlarına intikal tarihi başvuru veya bildirim tarihi olarak kabul edilir. Taahhütlü, iadeli taahhütlü, acele posta servisi, PTT Alo Post veya PTT Kargo ile yapılan başvuru ve bildirimlerde ise başvuru veya bildirimin postaya veya kargoya verildiği tarih; başvuru veya bildirim tarihi olarak dikkate alınır. 
2011/36 sayılı Genelge'de de açıkça Ek. m. 6 kapsamında sigortalı olmak "isteyenlerden" söz edilmektedir. Öyle ki hükme göre, Kanunun Ek 6" ncı maddesi kapsamında sigortalı olmak "isteyenler", "Şehir İçi Toplu Taşıma Araçlarında Kısmi Süreli Çalışanlara Ait Giriş Bildirgesi" ve araç sahibiyle şoför arasında imzalanan kısmi süreli iş sözleşmesi ile şoförlük mesleğini yaptıkları ilin sosyal güvenlik il müdürlügüne/sosyal güvenlik merkezine müracaat edeceklerdir (2.4.1.1).

2013/11 sayılı Genelgede verilenörnekte aynen şu ifadelere yer verilmiştir: "Kanun kapsamında 1/3/2011 tarihinden önce çalışması bulunmayan sigortalı (M), 2/2/2012 tarihinde gerekli onayları taşıyan belge ile Ek 6' ncı madde kapsamında sigortalı olmak için müracaat etmiştir. (M)'nin sigortalılığ 1 2/2/2012 tarihi itibariyle başlatılacaktır". Bildirim yapılıncaya kadar geçen sürenin tespitinin istenmesi mümkün değildir”. Oysa 5510 sayılı Kanuna göre iş sözleşmesi ile çalışanların sigortalılıkları, çalışmaya başladıkları an itibariyle başlar (m. 7/I, a). İşverenlerin çalışmaya başlamadan önce çalışacak kişileri, sigortalı işe giriş bildirgesi ile Kuruma bildirmeleri gerekir (m. 8/I, a). Sigortalılığın başlaması için kişinin bu yönde bir irade beyanı olmasa dahi kişinin hukuken sigortalılı̆g gerçekleşmiş sayılır. Hatta sigortalının işverence bildirilmemiş olmasının dahi sigortalılığın başlamasına bir etkisi yoktur. Daha açık bir deyişle Kuruma yapılan sigortalı işe giriş bildirimi kurucu değil, açıklayıcı niteliktedir ${ }^{31}$. Ek. m. 6 sigortalılığının, kendine özgü bir sigortalılık ilişkisi, istisnai bir düzenleme, hatta özel bir türde isteğe bağlı sigortalılık ilişkisi yarattığını ifade etmek hatalı olmayacaktır. İş sözleşmesi ile çalışmaya dayalı bir ilişkinin isteğe bağlı sigortalılık gibi düzenlenmiş olmasının yerinde olmadığ 1 kanaatindeyiz $z^{32}$.

Şehir içi toplu taşıma araçlarının (taksi, dolmuş, otobüs) geliş ve gidiş saatlerini kaydeden, bekleyen yolcuların sıra düzenini sağlayan ve araçlara binme işini yönlendiren kişilerin Kanunun Ek. 6'ncı maddesine göre sigortalılıklarının sağlanmasına yönelik müracaatlarında ise ücret aldığ 1 araç sürücüsü ile zabıtanın onayı yeterlidir ${ }^{33}$. Okul öncesi çocukları ve/ veya ilköğretim öğrencilerini taşıyan okul servis araçlarında rehber personel

31 Bkz. SÖZER, s. 31-32; DOĞAN, s. 430-431; GÜZEL/OKUR/CANİKLİOĞLU, s. 147-149; TUNCAY/EKMEKÇİ, s. 147-151; ARICI, s. 272-273; UŞAN, s. 119; KÖME AKPULAT, s. 1208.

32 CANIKLIOĞLU/ÖZKARACA, s. 657; benzer yönde KÖME AKPULAT, s. 1208.

33 2014/5 sayılı Genelge "Kanunun Ek 6 ncı Maddesi Kapsamında Çalışanlar" başlıklı üçüncü bölümü, "2.1- Sigortalılığın başlangıcı" maddesi. 
olarak çalışanların Ek 6'ncı madde kapsamında yapılacak müracaatlarında öğrencilerin bir ücret karşılığı taşımasını üstlenen gerçek veya tüzel kişi olarak tanımlanan taşımacı onayı ile taşımacılık özel izin belgesini onaylayan belediye onayı aranmaktadır ${ }^{34}$. Dolayısıyla adı geçenlerin onayı, çalışanın sigortalılı̆̆ını başlatmaktadır.

5510 sayıl1 Kanunun Ek 6'nc1 maddesi kapsamında sigortalı olmak için müracaat edenlerin ünitelerce öncelikle Kanunun 4'üncü maddesi kapsamında sigortalılığının bulunup bulunmadığı araştırılır. Ek 6'ncı maddeye müracaat ettiği tarihten önceki ay 4'üncü maddenin birinci fikrasının (a) bendi kapsamında çalışması var ise işten ayrılış bildirgesi verilip verilmediği sorgulanır. İşten ayrılış bildirgesi verilmemiş olanlar ile 4'üncü maddenin birinci fikrasının (b) bendi kapsamında sigortalılığ yapılmamış olanların Ek 6'ncı madde kapsamındaki talepleri reddedilir. Kanunun Ek 6'ncı maddesine göre müracaat eden sigortalıların müracaat tarihi itibariyle önceki sigortalılığının sona erip ermediğine bakılmaksızın Ek 6'ncı madde kapsamındaki sigortalılığının başlatıldığ tespit edilenlerden zorunlu sigortalılıkları Ek 6'ncı maddeye müracaat ettiği gün sona erenlerin, Ek 6' ncı maddeye tabi sigortalılıkları, takip eden gün başlatılır (2013/11 sayılı Genelge, üçüncü Bölüm, 3.2) ${ }^{35}$.

Kendi sigortalılıklarından dolayı aylık alan sigortalılara ilişkin olarak, 2013/11 sayılı Genelgede bir örnek verilmiştir. Örneğe göre hizmet akdine tabi ve ay içinde 10 günden az çalışması nedeniyle Kanunun Ek 6'ncı maddesine göre taksi şoförü olarak çalışmaktayken 21/11/2012 tarihinde aylık bağlanmas1 talebinde bulunan sigortalının Ek 6'nc1 madde kapsamındaki sigortalılı̆̆ 21/11/2012 tarihinde sona erdirilmiş, kişiye 1/12/2012 tarihinden geçerli olmak üzere yaşlılık aylığı bağlanmıştır. 15/2/2013 tarihinden itibaren taksi şoförlüğü yapmaya devam eden sigortalının aylık alması nedeniyle Ek 6'ncı madde kapsamında sigortalı sayılmasına imkan bulunmadığından, 15/2/2013 tarihinden itibaren işvereni tarafından Kanunun (a) bendi kapsamında sosyal güvenlik destek primine tabi tutulması gerekmektedir ${ }^{36}$. Nitekim örnekte de Ek. m. 6 sigortalılı̆̆ının sona erme tarihinin, hükme aykırılığın gerçekleştiği tarih olarak ifade edilecek olan aylık bağlanma talep tarihi olduğu tespit edilmelidir.

\footnotetext{
25/10/2017 tarihli ve 30221 sayılı Resmi Gazetede yayımlanan Okul Servis Araçları Hizmet Yönetmeliği m. 5/2, (c) ve m. 5/4.

35 01/09/2016 tarih, Say1: 84228040/ 642 ve 2013/11 say1l Genelgeye 2016/20 say1lı Genelge ile ek olarak getirilmiştir.

36 Ek, 28/2/2014 tarihli ve 2014/5 sayıl1 Genelge.
} 


\section{Prim Oranı, Prim Ödeme Gün Sayısı ve Prim Ödeme Yükümlüsüi}

Ek. m. 6 kapsamında sigortalı olanların, prime esas kazanç alt ve üst sınırı (asgari ücretin 6,5 katı) arasında olmak üzere ${ }^{37}$ kendileri tarafından belirlenecek günlük kazancın 30 katının \% 32,5'i oranında SGK'ya prim ödemeleri gerekmektedir (Ek. m.6/ IV). Ek. m. 6, sigortalılığı kendine özgü bir sigortalılık düzenlemek suretiyle, prim ödeme yükümlüsünün sigortalı olduğunu belirtmiştir. Oysa aynı işi yapan ve fakat ayda 10 gün ve üzerinde çalışan sigortalılar (m. 4/I,a'lılar) için prim ödeme yükümlüsü işverendir.

Ek. m. 6 kapsamında sigortalı olan çalışanın ödeyeceği prim oranının \% 20'si malûllük, yaşlılık ve ölüm sigortaları, \% 12,5'i genel sağlık sigortası primidir. İsssizlik sigortasına tabi olmayı isteyenlerin, sigortalı ve işveren hissesi oranındaki işsizlik sigortası primini ait olduğu ayı takip eden ayın sonuna kadar ödememeleri halinde, o aya ait işsizlik sigortası primini ödeme hakları düşmektedir (Ek. m. 6/IV) ${ }^{38}$.

Ek. m. 6’ya tabi sigortalılardan hükmün yürürlüğe girdiği yıl olan 2011 için prime esas günlük kazanç alt sınırı olan günlük asgari ücretin 18 katı prim matrahı üzerinden başlanılarak, takip eden her yıl için bir puan artırılmak suretiyle otuz katını geçmemek üzere prim alınması öngörülmüştür (5510 sK. m. Geçici m. 29). Başka bir deyişle on günden az çalışan Ek. m. 6 sigortalılarının primlerini alt kazanç sınırından ödemeleri halinde, geçici bir süre için, daha az gün karşıllı̆g prim ödemelerine rağmen otuz gün üzerinden prim ödemiş gibi sayılacakları kabul edilmiştir. 2011 yılından itibaren devlet katkısı uygulanmaktadır. Aylık 18 gün üzerinden prim alınmaya başlanmıştır. Anılan sigortalılar, 18 günün karşılığında 5510 sayılı Kanun m. 4/1, (a) kapsamında 30 günlük prim ödeme gün sayısı kazanmışlardır (30 günlük sigortalı sayılmışlardır). 2019 için, Ek. m. 6 sigortalılarının ödemeleri gereken aylık prim tutarı; prime esas günlük kazanç tutarının 26 katı üzerinden hesaplanmakta, 26 günlük ödenen prim 30 gün olarak kabul edilmektedir. Prime esas kazancın hesaplanacağı gün sayısı her yıl bir puan artırıldığından, 2023 yılında 30 güne ulaştığında tamamlanacak ve devlet katkısı da sona erecek ve sabitlenecektir. Sigortalılar 2023 yılına kadar, ay içerisinde daha az çalıştıkları halde kısmi süreli değil ve her yıl kademeli olarak artan şekilde prim ödemek suretiyle, her ay için 30 gün üzerinden emeklilik hakkını elde

37 Prime esas kazanç alt ve üst sınırı, 5510 sK. m. 82'de düzenlenmiştir.

38 İşsizlik sigortası hakkında değerlendirme aşağıda; "III, 4. Sigortalıların Faydalanacakları Sigorta Kolları” başlığı altında yapılacaktır. 
etmekte ve sağlık yardımlarından yararlanmaktadır. Böylece ödemedikleri bir süreyi de sigortalı olarak kazanmış sayılmakta, bu süreler yaşlılık ve ölüm aylığına hak kazanmada, malul sayılmada etkili olmaktadır ${ }^{39}$.

Sigortalının ay içinde birden fazla işte çalışmasına rağmen, toplam çalışması Ek. m. 6 kapsamında kalıyorsa, her bir sözleşme için primler ayrı ayr1 30 güne tamamlanmayacak; sigortalı, toplamda 30 günlük prim ödeme gün sayıs1 edinecektir.

Geçici madde 29, bu maddenin yürürlüğe girdiği y1l başlanmak suretiyle, kademeli şekilde artacak şekilde Ek. m. 6 sigortalısından prim alınacağını düzenlemiştir. Ek. m. 6 sigortalısının primlerini 30 güne tamamlayıp tamamlamamak noktasında seçimlik bir hakkının olduğuna ilişkin bir açıklık bulunmamaktadır. Başka bir deyişle, ayda 10 günden az çalışan kişinin, özellikle 2023'den sonra devlet katkısı da sona ereceği için, prim ödeme gün sayısını 30 güne çıkartıp çıkartmamayı, tercihe bağlı kılmamak kanaatimizce yerinde olmamıştır.

Öğretide, Ek. m. 6 kapsamında sigortalı olan kişiler, aylık prim ödeme gün sayısını 30'a çıkarmamışlarsa, bu kişilerin sosyal güvenceden yoksun kalacakları belirtilmiştir ${ }^{40}$. Söz konusu ifadeden, adı geçen görüşün prim ödeme gün sayısını 30'a çıkarıp çıkarmamak noktasında Ek. m 6 sigortalısına seçimlik bir hak tanındığı kanaatinde olduğu anlaşılmaktadır. Ek. m. 6 sigortalısının prim ödeme gün sayısını 30'a çıkarıp çıkarmama tercihinin kendisine ait olduğunun kabul edilmesi gerektiği görüşüne katılmakla birlikte, mevcut düzenlemeden tercihin Ek. m. 6 sigortalısına bırakılmadığını anlamaktayız. Zira Ek. m. 6' da şehir içi toplu taşıma araçlarında kısmi süreli iş sözleşmesiyle, ay içerisindeki çalışma gün sayısı 10'dan az olan kişilerin sigortalılıklarının, kendileri tarafından 30 gün üzerinden prim ödenmek suretiyle sağlandığı ifade edilmiştir. Yukarıda da belirttiğimiz üzere, anılan koşulun sigortalılık koşulu olarak düzenlendiği kanaatindeyiz ${ }^{41}$. Öğretide ifade edilen görüşün vardığ 1 sonucu yerinde bulmakla birlikte, Ek. m. 6 ve Geçici m. 29'un tereddüte mahal vermeyecek açıklıkta sigortalıya prim ödeme gün sayısını 30'a çıkarıp çıkarmamak noktasında tercih imkanı tanıması daha yerinde olacaktır. Zira, tüm Ek. m. 6'lıların prim ödeme gün sayılarını 30'a çıkarmak zorunda olduğu kabul edildiğinde, sigortalının ödemediği dönemler

\footnotetext{
39 LEVENT; SEGEKAM; MÜLAYIM.

40 TUNCAY/EKMEKÇI, s. 328.

41 Değerlendirme için bkz. III, 1, b. Ek. m. 6 Kapsamı Dışında Kalanlar.
} 
için gecikme zammı işleyecek, sigortalının belki de hiç ödemeyeceği bir borç yükü altında olduğu kabul edilecektir. Dolayısıyla, bu yükün altına girmek istemeyen kişi, Ek. m. 6 kapsamına girmek yerine, çalışmasını bildirmemeyi ve kayıtdışı kalmayı tercih edebilecektir.

Kanunun Ek. 6. maddesi kapsamında, on günden az çalışan sigortalıların primlerini alt kazanç sınırından değil de daha yüksek bir kazanç üzerinden ödemeleri halinde ise Geçici m. 29'un uygulama alanı bulup bulmayacağ1, daha açık bir deyişle primlerini alt kazanç sınırı üzerinden ödemeyenlerin de ödemedikleri sürelerin priminin ödenmiş gibi sayılıp sayılmayacağ 1 meselesi aydınlatılmalıdır. Kanaatimizce hükmün sadece primlerini alt kazanç sinırından ödeyen sigortalılara uygulanması yerinde olacaktır. Zira, hükmün hem lafzı açıktır hem de esasen primi ödenmeyen sürelerin primi ödenmiş gibi kabul edildiğinden, prime esas kazanç tutarı yükseldikçe Kurumun sigortalıya veya hak sahiplerine bağlayacağı aylığın miktarı da artacak, prime esas kazanç tutarı yükseldikçe hak sahiplerinin alacağı aylık miktarı artacağından primlerini alt kazanç sınırından daha yüksek bir kazanç üzerinden ödeyenlerin gelecekte alacakları aylık miktarı, kurumun aktüeryal dengesini bozacaktır ${ }^{42}$.

Ek. m. 6 sigortalısının tabi olacağı yükümlülükler ve haklar m. 4/I, (a)'lılardan tamamen farklıdır. Sosyal güvenlik hukukunda kural olarak 'iş sözleşmesi' ile çalışanlar yönünden prim ödeme yükümlüsü işverendir. Ek. m. 6 kapsamındakiler için ise prim ödeme yükümlüsü olarak sigortalı gösterilmiş, işverene hiçbir yükümlülük getirilmemiştir. Dolayısıyla araç sahibi işveren ile Ek. m. 6 kapsamında çalışan sigortalı arasında ayda 10 günden az çalışmayı içeren bir iş sözleşmesi yapılırsa, araç sahibinin çalışan için SGK'ya herhangi bir prim ödemesi gerekmemektedir. İş sözleşmesi ile çalıştı̆̆ için primleri işvereni ve kendisi tarafından karşılanacak ve tüm sigorta kollarına tabi olacak şekilde sosyal güvenceye kavuşturulması gereken kişiler, Ek. m. 6 ile hem prim ödeme yükümlüsü haline getirilmekte hem de daha az hak sağlanarak sosyal güvenceye kavuşturulmuş olmaktadır. Bu sistemde bir kişinin hangi kapsamda sigortalı sayılacağ1 aylık çalışması sona erdiğinde kesinleşmiş olacaktır ki, bazı durumlarda sigortalıyı Kuruma bildirmesi gereken işveren bakımından bir gecikme de söz konusu olabilecektir. Özellikle çağrı üzerine çalışmada bu olasılık sıklıkla gerçekleşebilecektir ${ }^{43}$. Şöyle ki, çağrı üzerine çalışmaya dayalı kısmi süreli iş sözleşmesinde, işçinin ayda kaç saat

\footnotetext{
42 CANIKLIIOĞLU/ÖZKARACA, s. 660-661.

43 CANIKLİĞLUU/ÖZKARACA, s. 647.
} 
çalışacağı önceden kararlaştırılabileceği gibi, çalışma süresine ilişkin hiçbir belirlemenin yapılmamış olması da mümkündür. Bu ihtimalde, İşK. m. 14/2 gereği, kişinin haftada 20 saat çalıştığı kabul edilecektir. Tarafların haftalık çalışma süresini baştan belirledikleri yahut hiç belirlemedikleri ihtimalde haftalık çalışma süresinin 20 saat olarak kabul edilecek olması sebebiyle, kişinin ayda 10 günden az veya çok çalışacağı baştan bilinebilir. Dolayısıyla söz konusu ilk iki ihtimalde sıkıntı yaşanmayacaktır. Sorun yaratacak ihtimal ise taraflarca kısmi süreli iş sözleşmesi ile işçinin ayda toplamda 10 günden az çalışacağı kararlaştırılmış olmasına rağmen, uygulamada işçinin çalışmasının ayda 10 günün üzerine çıkmasıdır. Bu durumda, işveren tarafından m. 4/I, (a) çerçevesinde sigortalı yapılması gereken işçi işe başladığında değil, ay sonunda Kuruma bildirilmiş olacaktır. İşverenin yaptırıma bağlanmaması açısından, sistemin bu açığının kapatılması gerekmektedir. Örneğin aylık çalışmanın beklenmeyen şekilde, 10 günü geçmesi üzerine, işverene belirli bir süre tanınmak suretiyle bildirim yapma ve diğer yükümlülüklerini tamamlama imkanı getirilebilir.

Öğretide Ek. m. 6 sigortalısının SGK'ya göre m. 4/a kapsamında 'işçi' sayıldığı, işlerini kendi işyerinde değil işverenin gösterdiği biçimde ve yerde yaptığg belirtilmiştir. Böyle iken, hiç olmazsa çalıştığı günlerin prim yükünden niçin öteki 4/a 'lılar gibi işverene de pay verilmediğinin ve o günlerin prim yükünün neden tümüyle işçi üzerinde bırakıldığının, ayrı bir anlaşılmazlık konusunu oluşturduğu üzerinde durulmuştur ${ }^{44}$. İş sözleşmesi ile çalışan bir kişinin sırf ay içindeki çalışma süresinin on gün veya daha az olması nedeniyle genel sigortalılık düzeninin dışına çıkarılmasına ilişkin düzenlemenin değiştirilmesi ve bu konuda sıkı ve yaygın bir denetim sisteminin uygulanması, anılan kişilerin sigortalılıklarının, m. 4/I, (a) bendine göre zorunlu sigortalılık çerçevesinde gerçekleştirilmesi gerekmektedir ${ }^{45}$. Ancak; taksi ve dolmuş şoförlerinin kendine özgü çalışmaları dikkate alınarak, gerektiği ölçüde, istisnai hükümlerin de getirilmesi uygun olacaktır.

Diğer taraftan, kanun hükmü ile primini çalışana ödetme imkânı yasal olarak getirilmişken; taksi, dolmuş, minibüste çalışan sigortalıların işverenlerinin tam süreli sözleşmeyle işçi çalıştırıp bildirge, prim belgesi verme ve prim ödeme yükümlüsü olmayı tercih etmesini beklemek, Türkiye

\footnotetext{
44 GÜZEL/OKUR/CANIKLİOĞLU, s. 136; UZUN.

45 CANIKLIOIĞLU/ÖZKARACA, s. 644-647.
} 
koşullarında pek de gerçekçi gözükmemektedir ${ }^{46}$. Dolayısıyla, Ek. m. 6 hükmünün ne yazık ki, kayıtlı çalışmayı artırmaktan ziyade, işverenlerin kayıt dışına atılması işlevini gördügü zamanla anlaşılacaktır.

\section{Sigortalıların Faydalanacakları Sigorta Kolları}

Ek 6. madde kapsamındaki sigortalılara; malullük ve yaşlılık aylığı, ölümleri halinde ise hak sahiplerine ölüm aylığı bağlanacak, ayrıca kendileri ya da bakmakla yükümlü oldukları kişiler, genel sağlı sigortasından sağlanan sağlık yardımlarından yararlanacaklardır (Ek. m. 6/III). Dolayısıyla uzun vadeli sigorta kollarından yararlanmak açısından m. 4/1, (a)'lılar ile Ek. m. 6'lllar açısından herhangi bir fark yoktur ${ }^{47}$. Ancak Ek. m. 6 kapsamındaki sigortalılar ve bakmakla yükümlü oldukları kişilerin, genel sağlık sigortası hükümlerinden yararlanabilmesi için 67' nci maddede sayılan diğer şartların (başka bir deyişle son bir yıl içinde toplam 30 gün genel sağ lık sigortası primi ödemiş olmasının) yanı sıra sağlık hizmeti sunucusuna başvurdukları tarihte 6183 sayılı Kanunun 48' inci maddesine göre tecil ve taksitlendirerek tecil ve taksitlendirmeleri devam edenler hariç 60 günden fazla prim ve prime ilişkin her türlü borcunun bulunmaması gerekmektedir (Ek. m. 6/VI). Bu demektir ki, Ek. m. 6 sigortalısından 60 günden fazla prim ve prime ilişkin hiçbir borcunun olmaması şartı aranmaktadır. Oysa, m. 4/1, (a) bendi kapsamındaki sigortalının genel sağlık sigortasından yararlanması için prim ve prime ilişkin hiçbir borcunun bulunmaması şartı aranmamaktadır. Ek. m. 6' lılar için böyle bir ek şart getirilmiş olmasını anlamak mümkün değildir ${ }^{48}$. Öyle ki, kanun koyucu bu kişileri, primlerin ödenmesi hususunda m. 4/(a)'lı kapsamında değil m. 4/(b)' li kapsamındaki sigortalılar gibi değerlendirmiştir ${ }^{49}$. Burada kendine özgü bir sigortalılık ilişkisi kurulmuştur. Ay içindeki çalışma gün sayıs1 10 gün veya daha fazla olan çalışanların prim ödeme yükümlüsü işverendir. İşverenlerin primleri zamanında ödememesi halinde dahi, sigortalı sağlık hizmetlerinden yararlanabilmektedir. Ay içindeki çalışma gün sayısı 10 günden az olanlar (Ek. m. 6'lılar) ise genel sağlık sigortası primlerini kendileri ödemekte ve daha da ötesi 60 günden fazla prim ve prime ilişkin herhangi bir borcunun bulunması halinde, kendileri ve bakmakla yükümlü oldukları kişiler sağlık hizmetlerinden yararlanamamaktadır ${ }^{50}$.

\footnotetext{
46 ŞAKAR, (2011), s. 9.

47 CANIKLIOĞLU/ÖZKARACA, s. 650.

48 CANIKLLIOĞLU/ÖZKARACA, s. 651; KÖME AKPULAT, s. 1201.

49 MÜLAYIM.

50 CANIKLIOĞLU/ÖZKARACA, s. 652.
}

Ankara Hacı Bayram Veli Üniversitesi Hukuk Fakültesi Dergisi C. XXIV, Y. 2020, Sa. 1243 
Diğer taraftan Ek. m. 6 sigortalılarına, yukarıda açıklanan prim borcu bulunmama koşulu dışında, genel sağlık sigortası açısından m. 4/I, (a)'lıların tabi olduğu esaslar uygulanacaktır. Örneğin Ek. m. 6 sigortalıları da, zorunlu sigortalılıklarının sona erdiği tarihten geriye doğru bir yıl içinde doksan günlük zorunlu sigortalılıkları varsa, sigortalılık niteliğini yitirdikleri tarihten itibaren doksan gün süreyle bakmakla yükümlü oldukları kişiler dahil sağlık hizmetlerinden yararlandırılacaklardır (m. 67/IV). Zira, Ek. m. 6/V'de açıkça, bu madde kapsamında ödenen primlerin, Kanunun 4' üncü maddesinin birinci fikrasının (a) bendi kapsamında sigortalılık olarak değerlendirildiği ifade edilmektedir ${ }^{51}$.

Ek. m. 6 kapsamındaki sigortalılar, 6111 sayılı Kanunla yapılan değişiklikten önceki hukuki durumdan farklı olarak, kısa vadeli sigorta kolları olan iş kazası ve meslek hastalığı, hastalık ve analık sigortası kollarından yararlanamayacaklardır ${ }^{52}$. Zira, Ek. m. 6/III'e göre, bu madde kapsamındaki sigortalılar hakkında; malûllük, yaşlılık ve ölüm sigortaları ile genel sağlık sigortası ve istekleri halinde işsizlik sigortası hükümleri uygulanır. Daha açık bir deyişle, Ek. m. 6/III'de, sigortalının hangi sigorta kollarından hangi şartlarla yararlanacağı belirlenmesine rağmen, kısa vadeli sigorta kolları zikredilmemiştir.

Kanun koyucu yine 6111 sayılı Kanunla eklenen Ek. m.5 hükmünde, tarım veya orman işlerinde iş sözleşmesiyle süreksiz olarak çalışanlar açısından, Ek. m.6 kapsamında sigortalılara benzer bir düzenleme getirmiş, ancak Ek. m.5'te ise bu sigortalılar hakkında malullük, yaşlılık ve ölüm sigortası ile genel sağlık sigortası hükümlerinin yanında iş kazası ve meslek hastalığı sigortasının da uygulanacağını öngörmüştür (f.III $)^{53}$.

Tüm bu hükümlerden hareketle, Ek. m. 6 kapsamında sigortalı olanlara, kendine özgü bir sigortalılık hali tanımlandığını ve bu kişilerin kısa vadeli sigorta kollarından hariç tutulduğunu ifade etmek gerekmektedir.

Kısa vadeli sigorta kolları kapsamına giren hallere ilişkin sağlik yardımlarının 5510 sayılı Kanun sisteminde genel sağlık sigortası çerçevesinde sağlandığı için, bu durumun sağlık yardımları açısından bir sakınca yaratmadığ 1 düşünülebilir. Ancak Ek. m. 6 sigortalıları, kısa vadeli sigorta kollarından

\footnotetext{
51 CANIKLLIOĞLU/ÖZKARACA, s. 652.

52 CANIKLIOGĞLU/ÖZKARACA, s. 655.

53 CANIKLİĞLU/ÖZKARACA, s. 656.
} 
sağlanan parasal yardımları alamazlar. Özellikle şoförlerin çalışma şartları itibari ile sürekli trafikte olmaları, birçok riski beraberinde getirmektedir. Örneğin araçlarında bulundukları sırada trafik kazası geçiren veya gasp ve şiddete maruz kalan Ek. m. 6 sigortalılarının iş kazası sigortasından yardım almaları; ölümleri hâlinde iş kazası sigortasından yakınlarına gelir bağlanması mümkün değildir. Ancak aylık çalışması 10 gün ve üzerinde olan çalışanların, taksi ve dolmuş sahibi tarafından sigortası yaptırıldıkları için bu kişiler adına $\% 2$ oranında kısa vadeli sigorta kolları (iş kazası ve meslek hastalığı, hastalık ve analık sigortası) primleri her ay (sigortalı ve işveren hisseleri) SGK'ya yatırılmaktadır. Adı geçen çalışanların, araçta bulundukları sırada başlarına gelen tüm olaylar (gasp, darp, kaza) iş kazası sayılmaktadır. Ölen taksi ve dolmuş çalışanlarının başta eşleri olmak üzere çocukları ile anne ve babalarına herhangi bir prim ve yaş şartı aranmaksızın SGK tarafından ölüm geliri bağlanması söz konusu olmaktadır ${ }^{54}$. Oysa Ek. m. 6 'dan önce, iş sözleşmesinin türü ve çalışma süresinin önemi olmaksızın, iş sözleşmesi ile araçlarda çalışanlar, m. 4/I, (a) bendi kapsamında zorunlu sigortalı sayıldıkları için işverenleri prim ödemek bir yana, SGK'ya işe giriş bildirgesini dahi vermemiş olsa, iş kazası ve meslek hastalığı yardımlarından faydalanabiliyorlard $1^{55}$. Ek. m. 6 düzenlemesinde kısa vadeli sigorta kollarının kapsam dışında bırakılmış olmasının önemli bir eksiklik olduğu, anılan maddenin Anayasa'nın eşitlik ilkesine aykırı ve temel sosyal güvenlik haklarını da ihlal ettiği ifade edilebilir ${ }^{56}$.

İşsizlik sigortası açısından ise Ek. m. 6 kapsamındaki sigortalılar, "istekleri halinde" işsizlik sigortası hükümlerinden yararlanabilirler (Ek. m. 6/III). Kanun koyucu işsizlik sigortası priminin ödenmesi konusunda kişileri serbest bırakmıştır. Ek. m. 6 sigortalısı, hem kendisine hem de işverene ait olan toplam $\% 3$ oranındaki işsizlik sigortası primini isterse ödeyebilir ve işsiz kaldığında, şartları da uygunsa, işsizlik sigortası fonundan faydalanabilir ${ }^{57}$. Oysa aylık çalışma gün sayısı 10 gün veya daha fazla olan sigortalılar, zorunlu olarak işsizlik sigortasının kapsamındadır (4447 sayılı İşsizlik Sigortası Kanunu m. 46/II). Nitekim işsizlik sigortasının zorunluluk niteliği gereği, doğal olan da budur. Ek. m. 6 sigortalılarının işsizlik sigortasından istekleri halinde faydalanabilmeleri yönündeki hüküm, işsizlik sigortasının

\footnotetext{
54 KARAKAŞ.

55 CANIKLIOĞLU/ÖZKARACA, s. 656.

56 TEZEL; KÖME AKPULAT, s. 1204; UZUN; MÜLAYIM.

57 MÜLAYIM.
}

Ankara Hacı Bayram Veli Üniversitesi Hukuk Fakültesi Dergisi C. XXIV, Y. 2020, Sa. 1245 
zorunluluğu ilkesine aykırıdır ${ }^{58}$. İlgili kısımlarda üzerinde durduğumuz üzere, Ek. m. 6 sigortalılığının kendine özgü bir sigortalılık ilişkisi kurduğu, temel esaslardan ayrıldığı burada da görülmektedir. Ancak, kanun koyucunun Ek. m. 6 sigortalılarına işsizlik sigortasını zorunlu tutmamasının, Ek. m. 6 sigortalılarının lehine olduğu belirtilebilir. Zira işsizlik sigortasından yararlanmak için son üç yıl içinde en az 600 gün sigortalı olarak çalışıp işsizlik sigortası primi ödemiş olma ve iş sözleşmesinin sona ermesinden önceki son 120 gün iş sözleşmesiyle çalışmış olma ${ }^{59}$ şeklinde sıkı koşullar söz konusudur. Ek. m. 6 sigortalılarının işsizlik sigortasına ilişkin koşulları sağlaması mümkün olmayabilir. Dolayısıyla yararlanma imkanı bulamayacakları bir sigorta kolu için prim ödememe imkanı ya da bu sigorta koluna tabi olmayı istemeleri halinde, otuz gün üzerinden prim ödeyerek sigortadan yararlanma imkanı sağlandığı şeklinde bir görüş ileri sürülebilir. Ancak, öğretide kısmi süreli iş sözleşmesi ile oldukça kısa süreli çalışanlar açısından dahi var olan bu sigorta kolunun, prim ödeme konusunda sadece Ek. m. 6'lı sigortalılar için ayrık düzenleme getirmesini haklı bir gerekçe olarak değerlendirmenin mümkün olmadığı belirtilmiştir. Aynı görüşe göre, kısmi süreli sözleşme ile çalışanlar için m. 51/II'de öngörülen, ay içindeki çalışmalarının otuz günden eksik kalan kısmının primlerini isteğe bağlı sigorta kapsamında ödeyebilme olanağı, 6111 sayılı Kanunla uzun vadeli sigorta kolları ve genel sağlık sigortası gibi işsizlik sigortası primleri için de geçerli olduğundan, Ek. m. 6 ile yeni bir imkanın sağlandığından söz edilemez ${ }^{60}$. Yukarıda anılan görüşü hukuka uygun bulmakta ve Ek. m. 6 kapsamındaki sigortalıların, sadece "istekleri halinde" işsizlik sigortası hükümlerinden yararlanabilmelerini mümkün kılan Ek. m. 6/III'ün, işsizlik sigortasının zorunluluğu ilkesine aykırı olduğunu kabul etmekteyiz. Tüm bunlara rağmen; Ek. m 6 sigortalılarının işsizlik sigortasından tercihe bağlı olarak yararlanmalarını düzenleyen Ek. m. 6/III, kanaatimizce yerinde bir düzenlemedir. Zira, tüm primleri sigortalıların ödeyecekleri şekilde tasarlanmış olan sistemin, en azından yararlanmaları çok mümkün olmayacak olan işsizlik sigortası primini ödemekten kaçınma imkanı sağlayacak şekilde bir seçenek sunması, uygundur. Elbette ideal olan işsizlik sigortasının zorunluluğudur. Fakat idealin savunulması için diğer hükümlerin

58 CANIKLİĞLU/ÖZKARACA, s. 653. İşsizlik sigortasının zorunluluk niteliği için bkz. ANDAÇ, s. 41; BAŞTERZİ, s. 93; ÖZKARACA, s. 22.

594447 sayılı Kanun m. 50/II'de yer alan "prim ödeyerek sürekli çalışmış" ibaresi, 17/1/2019 tarihli ve 7161 sayılı Kanunun 25 inci maddesiyle "hizmet akdine tabi" şeklinde değiştirilmiştir.

60 CANIKLIIOĞLU/ÖZKARACA, s. 653-654; benzer yönde KÖME AKPULAT, s. 1209. 
de genel düzenin dışına çıkmamış olması gerekir. Başka bir deyişle, Ek. m. 6 sigortalılı̆̆ı, m.4/I,(a)'lılı̆̆ın sağladığı tüm imkanları Ek. m. 6'lilara da sağlasayd1, elbette değerlendirmemiz farklı olurdu.

\section{Ek. m. 6 Sigortalılığının Sona Ermesi}

Ek. m. 6'ya göre sigortalının sahip olduğu hak ve yükümlülükler, birinci fıkrada belirtilen şekildeki çalışma durumlarının son bulmasından itibaren sona erer (Ek. m. 6/III). Dolayısıyla; ticari taksi, dolmuş ve benzeri nitelikteki şehir içi toplu taşıma aracı işyerlerinde kısmi süreli iş sözleşmesiyle çalıştıkları kişi yanında ay içerisinde çalışma saati süresine göre hesaplanan çalışma gün sayısı 10 günden az olan çalışmanın son bulması veya hesaplanan çalışma gün sayısının 10 gün ya da üzerinde olduğunun tespit edilmesi halinde, çalışanın bu kapsamdaki sigortalılığg ortadan kalkar.

Ek. m. 6 sigortalısının sigortalılı̆̆ının sona ermesi, sigortalıyla işveren arasındaki iş ilişkisinin taraflardan birinin sözleşmeyi feshi, sözleşmedeki işin bitmesi yahut tarafların anlaşarak iş ilişkisini sona erdirdiklerinin SGK'ya bildirilmesiyle gerçekleşir ${ }^{61}$. Ancak, sigortalılığın sona ermesi için Kuruma bir bildirim yapmak şart değildir ${ }^{62}$. Burada sona erme tarihinin, hükme aykırılığın gerçekleştiği tarih olarak kabul edilmesi gerekmektedir. Daha açık bir deyişle, sona erme tarihi, örneğin Ek. m. 6 sigortalısının m. 4, I, (a) bendi kapsamında tam süreli çalışmaya başladı̆̆ı tarih olmalıdır.

Ek. m. 6 sigortalısının bu sigorta kapsamında birden çok işverenle iş ilişkisi sürerken, birinin devam etmesi koşuluyla, diğerlerinin feshi veya işten ayrılışlarının bildirilmesi halinde, o çalışanın Ek. m. 6 sigortalılığı devam eder. Zira Ek. m. 6 sigortalılı̆̆ının işten ayrılmayla bitmesi için, sigortalının tüm kısmi süreli iş sözleşmelerinin bitmiş ya da feshedilmiş, bütün işlerinden ayrılışlarının bildirilmiş olması gerekmektedir. Ek. m. 6 kapsamında bildirilmiş bir tek iş bile Ek. m. 6 sigortalılığının devam etmesi için yeterlidir ${ }^{63}$.

Çalışanın sigortalılığı, Ek. m. 6’nın birinci fikrasında belirtilen şekildeki çalışma durumlarının son bulması dışında da sona erebilir. Ek. m. 6/VII ve

\footnotetext{
${ }_{61}$ 2013/11 sayılı Genelgede değişiklik yapan 2016/20 sayılı Genelgeye göre Kanunun Ek 6 ncl Maddesi Kapsamında Çalışanlar" başlıklı üçüncü bölümün "4-Sigortalılı̆̆ın sona ermesi" alt başlığının birinci paragrafının son cümlesi aşağıdaki şekilde değiştirilmiştir.

"Ayrıca, Ek 6 ncı madde kapsamında çalışanların sigortalıkları işten ayrıldıklarının kendileri veya bunları çalıştıran kişilerin/işverenlerin bildirimi halinde de sona erdirilir."

${ }^{62}$ CANIKLIOĞLLU/ÖZKARACA, s. 661.

63 UZUN.
} 
2013/11 sayıl1 Genelgede ${ }^{64}$ bazı kişilerin Ek. 6' ncı madde kapsamında sigortalı sayılmayacakları düzenlenmiştir. Hükümlerin mevhumu muhalifi gereği, Ek 6'ncı madde kapsamında sigortalı sayılmayacakların, Ek. m. 6 sigortalıs1 olması halinde, bu kişilerin sigortalılıkları sonradan sona erer. Bu haller: Ek. m. 6 sigortalısının; Kanunun 4 üncü maddesinin birinci fikrasının (a) bendi (b) ve (c) bentleri kapsamında uzun vadeli sigorta kollarına tabi sigortalı çalışması, isteğe bağlı sigortalı olmas1 ${ }^{65}$, 506 sayılı Kanunun geçici 20 'nci maddesi kapsamındaki sigortalı olması ile kendi sigortalılıklarından dolay1 gelir veya aylık almasıdır. Dolayısıyla zikredilen durumların gerçekleşmesi halinde de, kişinin Ek. m. 6 sigortalıllı̆ 1 sona erecektir ${ }^{66}$.

2014/32 say1lı Genelge ile 2013/11 sayılı Genelgenin ikinci kısmında yapılan düzenlemelere göre "Kanunun Ek 6'nc1 maddesi Kapsamında Çalışanlar" başlıklı üçüncü bölümün "4- Sigortalılı̆̆ın sona ermesi" alt başlı̆̆ının birinci paragrafındaki "işten ayrılması" ibaresinden sonra gelmek üzere "ve ölümü" ibaresi eklenmiştir. Hükümden hareketle, Ek. m.6 sigortalılığını sona erdiren bir diğer durumun sigortalının ölümü olduğu sabittir.

\section{Gecikme Cezası ve Zammı ile İdari Para Cezası}

Kanun koyucu Sosyal Güvenlik Kurumuna, bu madde kapsamındaki sigortalıların bu Kanunun diğer hükümlerine göre uzun vadeli sigorta kollarına tabi olma durumlarını dikkate alarak prim ödeme gün sayılarını ve prim ödeme sürelerini belirleme, bu sigortalıları çalıştıranlara ve çalıştıranların bağlı olduğu meslek odası, birlik veya benzeri kuruluşlara Kurumca belirlenecek süre içinde bu sigortalıların işe başlama ve işten ayrılışlarını bildirme, bu madde veya bu Kanunun uzun vadeli sigorta kollarını ihtiva eden sigortalılık statüleri kapsamında sigortalılık kontrolünden sonra çalıştırılmaları, çalıştırıldıkları süre içerisinde sigortalılıklarının devam edip etmediği ve Kurumca verilecek sigortal1lık belgelerinin periyodik kontrolünü sağlama hususunda zorunluluk getirme yetkisi, vermiştir (Ek. m. 6/VIII).

Hükmün devamında, bu madde kapsamında bulunan sigortalıları çalıştıranlar ile çalışanların üye olduğu meslek odası, birlik veya

\footnotetext{
${ }^{64}$ SGK'nın Sigortalılık İşlemleri hakkında 2013/11 sayılı Genelgesi.

65 İsteğe bağlı sigortalı olmanın, Ek. m. 6 kapsamında sigortalı olmayı sona erdireceğine ilişkin eleştriler için bkz. CANIKLİĞGU/ÖZKARACA, s. 661-662.

${ }_{66}$ Ek. m. 6/VII ve 2013/11 sayılı Genelge'de yer verilen ve Ek. m. 6 sigortalılığını sona erdiren hallere ilişkin değerlendirmemiz, "III, 1, b" başlığı altında yapıldığg için, burada tekrardan kaçınılmıştır.
} 
benzeri kuruluşlara bu madde uyarınca getirilecek bildirim ve kontrol yükümlülüklerinin yerine getirilmemesi halinde de 102' nci madde uyarınca idari para cezası uygulanacağı düzenlenmiştir (Ek. m. 6/IX).

5510 sayılı Kanunun atıf yapılan 102. maddesine göre ise Ek 6' nc1 maddeye göre yapılması gereken bildirim veya kontrol yükümlülüğünün yerine getirilmemesi halinde, her bir fiil için asgari ücret tutarında idari para cezas1 uygulanır (5510 sK. m. 102/1) ${ }^{67}$.

Diğer taraftan 2013/11 say1lı Genelge ile de 'Kanunun Ek 6' ncı maddesi kapsamındaki sigortalıların, her aya ait primlerini ilgili ayı takip eden ayın sonuna kadar Kuruma ödemeleri gerektiği belirtilmiştir. Yasal süresi içinde ödenmeyen primlere Kanunun 89'uncu maddesi gereğince ödenme tarihine kadar gecikme cezası ve gecikme zammı uygulanacaktır (Üçüncü Bölüm, 5-Primlerin Hesabı, Gün sayısı ve Ödenmesi) ${ }^{68}$.

Kanun koyucu Ek. m.6'nın uygulanmasına ilişkin usul ve esaslar Kurum tarafindan çıkarılacak yönetmelikle düzenleneceğini ifade etmişse de, konu hakkında bir Yönetmelik hâlâ çıkarılmamıştır (Ek. m 6/son).

\section{SONUC}

Yüksek oranda kayıt dış1lığın olduğu taksi, dolmuş ve buna benzer şehir içi toplu taşıma araçlarında çalışan kişileri çalışma şekilleri açısından üçe ayırmak mümkündür. Bunlardan ilki araç sahipleri, ikincisi araçları sahibinden kiralamak suretiyle aracı kendi adlarına işletenler ve üçüncüsü araçlarda iş sözleşmesi ile ücretli çalışanlardır.

Kanun koyucu 5510 sayılı Kanuna getirdiği Ek. m. 6 hükmü ile şehir içinde ticari taksi, dolmuş ve benzeri nitelikteki şehir içi toplu taşıma araçlarında ücretli olarak, bir veya birden fazla kişi yanında, ay içerisinde çalışma saati süresine göre hesaplanan çalışma gün sayısı 10 günden az olanların, kendileri tarafindan ve 30 gün üzerinden prim ödemeleri suretiyle, sigortalı olabileceklerini düzenlemiştir. İş sözleşmesi ile çalışanları, çalışma gün sayısı ayda 10 günden az ve çok şeklinde ikiye bölmek suretiyle getirilen sistem, kanaatimizce birçok yönden eleştiriye açıktır.

Ek. m. 6 gereği, şehir içinde ticari taksi, dolmuş ve benzeri nitelikteki toplu taşıma araçlarında birden fazla çalıştıran yanında ve her bir çalıştıranda

676111 say1lı Kanunun 45. maddesiyle 13/2/2011'de ek olarak getirilmiştir.

68 01/09/2016 tarih, Sayı: 84228040/ 642 ve 2013/11 sayılı Genelgede Değişiklik konulu Genelge. 
ayda 10 günden az çalışmak üzere toplamda ayda 10 günden fazla çalışan kişinin, Ek. m. 6'lı olması mümkün değildir. Oysa ev hizmetlerinde çalışanların sigortalılı̆̆ını düzenleyen Ek. m. 9 kapsamında her bir çalıştıran nezdinde ayda 10 günden az çalışma halinde, kişinin her bir çalışması için Ek. m. 9 sigortalısı olması mümkündür.

Aynı yönde olmak üzere, Ek. m. 6/VII ve 2013/11 sayılı Genelgeyle, Ek. m. 6 kapsamına girebilecek bir kısım kişilerin Ek. m. 6'lı olamayacağ düzenlenmiştir. Özellikle kısmi süreli bir çalışması olan veya isteğe bağlı sigortalı olan kişinin, ayrıca Ek. m. 6 kapsamına girecek bir işte çalışması halinde, Ek. m. 6'lı olabilmesi kanaatimizce mümkün olmalıdır. Ek. m. 6'da yapılacak değişikliklerle, olumsuz sonuçlar yaratan bu düzenlemeler yeniden düzenlenmelidir.

Çalışma süresi ayda 10 günden az dahi olsa, kişi kısmi süreli çalışıyorsa (tam süreli sözleşmelerde olduğu gibi), bu kişinin işvereni onu çalışmaya başlamadan önce Kuruma bildirmelidir. Yine kişi çalışmaya başlamakla kendiliğinden ve zorunlu olarak sigortalı olmalıdır. Sigortalı olmayı tercih edip etmeme şeklinde bir ayrım söz konusu olmamalıdır. Ek. m. 6'da düzenlenen sigortalılıkta, zorunluluk ilkesinden ayrılınmıştır. Ek. m.6'lıların sigortalılığı, genel kural olan fiilen işe başlamayla değil, çalışmanın kuruma bildirildiği gün başlamaktadır (Ek. m. 6/II). Bu çerçevede iş sözleşmesi ile çalışmaya dayalı bir ilişkinin isteğe bağlı sigortalılık gibi düzenlenmiş olması da kanaatimizce yerinde değildir.

Ayda on günden az çalışan Ek. m. 6 sigortalılarının primlerini alt kazanç sınırından ödemeleri halinde, geçici bir süre için, daha az gün karşılığı prim ödemelerine rağmen otuz gün üzerinden prim ödemiş gibi sayılacakları kabul edilmiştir. Ek. m. 6 hükmünün en olumlu yanı olarak değerlendirdiğimiz bu düzenlemenin, prime esas kazancın hesaplanacağ1 gün sayısı her yıl bir puan artırıldığından, 2023 yılında 30 güne ulaşılacağı ve devlet katkısının sona ereceği, dolayısıyla anılan faydanın 2023 yılında ortadan kalkacağ1 belirtilmelidir.

Diğer taraftan Ek. m. 6 kapsamındaki sigortalılar ve bakmakla yükümlü oldukları kişilerin, genel sağlık sigortası hükümlerinden yararlanabilmesi, son bir yıl içinde toplam 30 gün genel sağlık sigortası primi ödemiş olmalarının yanı sıra, sağlık hizmeti sunucusuna başvurdukları tarihte 60 günden fazla prim ve prime ilişkin her türlü borçlarının bulunmamasına bağlıdır (Ek. m. 6/VI). Oysa, m. 4/1, (a) bendi kapsamındaki sigortalının genel sağlık 
sigortasından yararlanması için prim ve prime ilişkin hiçbir borcunun bulunmaması aranmamaktadır. Ek. m. 6' lılar için böyle bir ek şart getirilmiş olmasını anlamak mümkün değildir.

Ek. m. 6 kapsamındaki sigortalılar, kısa vadeli sigorta kollarından hariç tutulmuştur (Ek. m. 6). Özellikle şoförlerin çalışma şartları itibari ile sürekli trafikte olmaları, birçok riski beraberinde getirmektedir. Ek. m. 6 düzenlemesinde kısa vadeli sigorta kollarının kapsam dışında bırakılmış olmasının önemli bir eksiklik olduğu, anılan maddenin Anayasa'nın eşitlik ilkesine aykırı ve temel sosyal güvenlik haklarını da ihlal eder cinsten olduğu belirtilmelidir.

5510 sayılı Yasanın Ek 6. maddesi, ilgili maddenin gerekçesinde ifade edildiği üzere, kayıtdışı çalışmayı azaltmayı amaçlamaktadır. Ancak hükümde sosyal güvenlik hukukunun temel prensiplerine aykırı düzenlemeler olduğu gibi, Ek. m. 6'nın kayıtdışı çalışmayı azaltması pek mümkün gözükmemektedir. Kanaatimizce, öncelikle taksi, dolmuş gibi şehir içi toplu taşıma araçlarında çalışanların diğer iş sözleşmeleriyle çalışanlarla aynı hükümlere tabi olması ve denetimlerin artırılması suretiyle, adı geçen kişilerin sosyal güvenliklerinin tam olarak sağlanması gerekmektedir. Ancak mevcut Ek. m. 6 üzerinden ilerlenecekse, çalışmamızda değerlendirmeye çalıştığımız Ek. m. 6 üzerindeki değişiklikler yapılmak suretiyle, hükmü gerçek amacına ulaşır hale getirmek gerekmektedir. Ek. m. 6'nın tümden kaldırıldığı çözümde, adı geçen kişilerin çalışmalarına özgü, istisnai hükümlerin belirlenmesi elbette yerinde olacaktır.

\section{KAYNAKÇA}

ALPER, Yusuf: Türk Sosyal Güvenlik Sistemi, Sosyal Sigortalar Hukuku, VIII. Bask1, Dora Yayınevi, Bursa, 2016.

ANDAÇ, Faruk: İşsizlik Sigortası, I. Baskı, Tühis yayınları, Ankara, 1999.

ARICI, Kadir: Türk Sosyal Güvenlik Hukuku, I. Baskı, Gazi Yayınevi, Ankara, 2015.

BAŞTERZİ, Süleyman: İşsizlik Sigortası, I. Baskı, Ankara Üniversitesi Hukuk Fakültesi Yayınevi, Ankara, 1996. 
CANİKLIOĞLU, Nurşen/ÖZKARACA, Ercüment: "Sanatçıların Sosyal Güvenliği", İstanbul Üniversitesi Hukuk Fakültesi Mecmuası, C. LXXII, S. 2, 2014, s. 637-664. (http://dergipark.ulakbim.gov.tr/iuhfm/, erişim: 2.3.2019)

DOĞAN, Kübra: "Sosyal Sigorta İlişkisinin Hukuki Niteliği Üzerine Bir Deneme", İş Hukuku Dergisi, C. 3, S. 3, 1993, s. 428-436.

GÜZEL, Ali/OKUR, Ali Rıza/CANIKLİĞLU, Nurşen: Sosyal Güvenlik Hukuku, XVII. Bask1, Beta Yayınevi, İstanbul, 2018.

KARAKAŞ, İsa: "Taksici ve dolmuşçular! SGK sigortasında bu püf noktaları kaçırmayın", (https://www.turkiyegazetesi.com.tr/yazarlar/isakarakas/603192.aspx, erişim: 2.3.2019).

KÖME AKPULAT, Ayşe: "Sanatçıların Sosyal Güvenliği”, Prof. Dr. Fevzi Şahlanan'a Armağan, İstanbul Üniversitesi Hukuk Fakültesi Mecmuası, S.LXXIV, Özel Say1, C.2, İstanbul, 2016, s. 1185-1209 (http://dergipark.ulakbim.gov.tr/iuhfm/, erişim: 2.3.2019).

LEVENT, Recep: "Ticari Olarak Çalışan Şoförlerin Sosyal Güvenliğii", (https://www.isvesosyalguvenlik.com/ticari-olarak-calisan-soforlerinsosyal-guvenligi/, erişim: 2.3.2019).

MÜLAYİM, Oğuz: "Ticari Taksi Dolmuş Ve Benzeri Ulaşım Araçlarında Şoför Olarak Kısmi Süreli Çalışan Kişilerin Sigortalılıkları”. (http:// www.alomaliye.com/2012/06/25/ticari-taksi-dolmus-sofor-kismi-surelicalisanlarin-sigortaliliklari/, erişim: 2.3.2019).

ÖZKARACA, Ercüment: İşsizlik Sigortası Kapsam ve Yardımları, Yayımlanmamış Yüksek Lisans Tezi, İstanbul, 2002.

SEGEKAM: "Geçmişten Günümüze Taksi Şoförlerinin Durumu”. (http:// segekam.com/calisma-dunyasi/sigortali/taksicilerin-sigorta-cikmazi. html, erişim: 2.3.2019).

SÖZER, Ali Nazım: Sosyal Sigorta İlişkisi, Dokuz Eylül Üniversitesi Yayın No:0906, İzmir, 1991.

ŞAKAR, Müjdat: Sosyal Sigortalar Uygulaması, XII. Baskı, Beta Yayınevi, İstanbul, 2017 (ŞAKAR, (2017)). 
ŞAKAR, Müjdat: “Taksi, Dolmuş ve Minibüs Şoförlerinin Sigortalılığı”, Yaklaşım Dergisi, S. 217, Ocak 2011. (https://docplayer.biz. tr/24110811-Taksi-dolmus-ve-minibus-soforlerinin-sigortaliligi.html, erişim: 2.3.2019) ((ŞAKAR, (2011)).

TEZEL, Ali: "Taksi şoförleri pirimlerini kendi cebinden ödeyecek". (https:// www.bloomberght.com/ht-yazarlar/ali-tezel/865559-taksi-soforleripirimlerini-kendi-cebinden-odeyecek, erişim: 2.3.2019).

TUNCAY, Can/EKMEKÇİ, Ömer: Sosyal Güvenlik Hukuku Dersleri, XIX. Bask1, Beta Yayınevi, İstanbul, 2017.

UŞAN, Fatih: Türk Sosyal Güvenlik Hukukunun Temel Esasları, II. Bask1, Seçkin Yayınevi, Ankara, 2009.

UZUN, Yaşar: "5510 sayı1ı Yasanın Ek 6. Maddesi Kapsamında Sanatçıların İşe Giriş, Çalışma Süreci ve İşten Çıkış Uygulamaları" (http://www. muhasebetr.com/yazarlarimiz/hyasaruzun/001/, erişim: 2.3.2019).

YILMAZ, Mustafa/ÇAKAR Erden: "Şoförlerin Sosyal Güvenliği Nasıl Sağlanacak", Yaklaşım Dergisi, S. 217, Ocak, 2011 (https://www. ozdogrular.com/v1/content/view/14892/254/, erişim: 2.3.2019). 
Ankara Hacı Bayram Veli Üniversitesi Hukuk Fakültesi Dergisi C. XXIV, Y. 2020, Sa. 1 